\title{
BOREAS
}

\section{Deglacial to postglacial palaeoenvironments of the Celtic Sea: lacustrine conditions versus a continuous marine sequence}

\begin{tabular}{|c|c|}
\hline Journal: & Boreas \\
\hline Manuscript ID: & BOR-011-2013 \\
\hline Manuscript Type: & Original Article \\
\hline Date Submitted by the Author: & 21-Jan-2013 \\
\hline Complete List of Authors: & $\begin{array}{l}\text { Furze, Mark; MacEwan University, Earth \& Planetary Sciences Division, } \\
\text { Department of Physical Science } \\
\text { Scourse, James; Bangor University, School of Ocean Sciences; Bangor } \\
\text { University, School of Ocean Sciences } \\
\text { Pienkowski, Anna; Bangor University, School of Ocean Sciences } \\
\text { Marret, Fabienne; University of Liverpool, Geography } \\
\text { Hobbs, William; Science Museum of Minnesota, St. Croix Watershed } \\
\text { Research Station } \\
\text { Carter, Rosemary; Bangor University , School of Ocean Sciences } \\
\text { Long, Brian; Bangor University, School of Ocean Sciences }\end{array}$ \\
\hline Keywords: & $\begin{array}{l}\text { Celtic Deep Basin, NW European continental shelf, sea-level, molluscs, } \\
\text { microfossils, glacimarine, glacilacustrine }\end{array}$ \\
\hline
\end{tabular}


1

2

3

4

5

6

7

8

9

10

11

12

13

14

15

16

17

18

19

20

21

22

23

24

25

26

27

28

29

30

31

32

33

34

35

36

37

38

39

40

41

42

43

44

45

46

47

48

49

50

51

52

53

54

55

56

57

58

59

60

1 Deglacial to postglacial palaeoenvironments of the Celtic Sea: lacustrine conditions versus a

2 continuous marine sequence

3

4 MARK F.A. FURZE, JAMES D. SCOURSE, ANNA J. PIEŃKOWSKI, FABIENNE MARRET, WILLIAM O.

5 HOBBS, ROSEMARY A. CARTER, AND BRIAN T. LONG

6

7 Mark F.A. Furze (e-mail: furzem@macewan.ca), Earth \& Planetary Sciences Division, Department of

8 Physical Sciences, MacEwan University, Edmonton, Alberta T5J 4S2, Canada; James D. Scourse, Anna

9 J. Pieńkowski, Rosemary A. Carter, and Brian T. Long, School of Ocean Sciences, College of Natural

10 Sciences, Bangor University, Menai Bridge LL59 5AB, UK; Fabienne Marret, School of Environmental

11 Sciences University of Liverpool, Liverpool L69 7ZT, UK; William O. Hobbs, St. Croix Watershed

12 Research Station, Science Museum of Minnesota, $16910152^{\text {nd }}$ Street North Marine on St. Croix, MN

1355047, USA 
15 Recent work on the last glaciation of the British Isles has led to an improved understanding of the

16 nature and timing of the retreat of the British-Irish Ice Sheet (BIIS) from its southern maximum (Isles

17 of Scilly), northwards into the Celtic and Irish seas. However, the nature of the deglacial

18 environments across the Celtic Sea shelf, the extent of subaerial exposure, and the existence (or

19 otherwise) of a contiguous terrestrial linkage between Britain and Ireland following ice retreat

20 remains ambiguous. Multiproxy research, based on the analysis of BGS vibrocores from the Celtic

21 Deep Basin (CDB), seeks to address these issues. CDB cores exhibit a shell-rich upward fining sequence of Holocene marine sand above an erosional contact cut in laminated muds with infrequent lonestones. Molluscs, in situ foraminifera, and marine diatoms are absent from the basal muds, but rare damaged freshwater diatoms and foraminiferal linings occur. Dinoflagellate cysts and non-pollen palynomorphs evidence diverse, environmentally incompatible floras with temperate, boreal, and Arctic glacimarine taxa co-occurring. Such multiproxy records can be interpreted as representing a retreating ice margin, with reworking of marine sediments into a lacustrine basin. Equally, the same record may be interpreted as recording similar conditions within a semi-enclosed marine embayment dominated by meltwater export and deposition of reworked microfossils. Since assemblages from these cores contrast markedly with proven glacimarine sequences from outside

31 the $C D B$, a glacilacustrine interpretation is favoured for the laminated sequence, truncated by a Late

32 Weichselian transgressive sequence fining upwards into fully marine conditions. Reworked rare

33 intertidal molluscs from immediately above the regional unconformity provide a minimum date

$34 \sim 13.9$ cal ka BP for commencement of widespread marine erosion. Though suggestive of

35 glacilacustrine conditions, the exact nature and timing of laminated sediment deposition within the

$36 \mathrm{CDB}$, and the implications this has on (pen)insularity of Ireland following deglaciation, remain

37 elusive. 
1

2

3

4

5

6

7

8

9

10

11

12

13

14

15

16

17

18

19

20

21

22

23

24

25

26

27

28

29

30

31

32

33

34

35

36

37

38

39

40

41

42

43

44

45

46

47

48

49

50

51

52

53

54

55

56

57

58

59

60

39 Keywords: Celtic Deep Basin, Northwest European continental shelf, sea-level, molluscs,

40 microfossils, glacimarine, glacilacustrine 


\section{1. Introduction}

42 Elucidating the nature and timing of deglaciation in the Celtic and Irish seas at the end of the

43 Weichselian Cold Stage and their associated sea-level histories has significant implications for

44 understanding the development of insularity between Britain and Ireland along with the

45 concomitant effects that this had on the evolving biogeographies of these regions (Stuart 1977,

46 1995; Devoy 1986, 1995; Coxon \& Waldren 1995). Much work has been conducted in the northern

47 part of this area (Irish and Malin seas; e.g. Clark et al. 2004; Thomas et al. 2004; McCabe et al. 2005;

48 Roberts et al. 2007; van Landeghem et al. 2009; Roberts et al. 2011) and increasingly along the

49 coasts of the Celtic Sea (e.g. Ó Cofaigh \& Evans 2001a; Evans \& Ó Cofaigh 2003; Hiemstra et al. 2006;

50 McCarroll et al. 2010). However, important evidence for ice occupation and subsequent deglaciation

51 at the southern limit of the British-Irish Ice Sheet (BIIS) and the implications this has for ice sheet

52 dynamics and stability, and sediment delivery to the North Atlantic, lies offshore on the floor of the

53 Celtic Sea (Pantin \& Evans 1984; Evans 1990; Scourse et al. 1990, 1991, 2009; Tappin et al. 1994).

54 Furthermore, establishing the deglacial to postglacial marine evolution of shelf seas is important

55 given the role such systems play in global ocean productivity (Wollast 1991; Austin \& Scourse 1997;

56 Marret \& Scourse 2002; Scourse et al. 2002; Scourse in press), as well as $\mathrm{CO}_{2}$ ocean-atmosphere

57 exchange during climate transitions (Rippeth et al. 2008).

58 Despite a number of observational and glacial isostatic adjustment (GIA) modelling

59 simulations, the extent to which the shallow continental shelf of the Celtic Sea was exposed

60 subaerially following deglaciation and during the Holocene marine transgression remains unresolved

61 (Devoy 1983, 1985, 1995; Lambeck 1995, 1996; Wingfield 1995; Lambeck \& Purcell 2001; Peltier et

62 al. 2002). Fundamentally, did deglaciation occur in a tidewater setting followed by uninterrupted

63 postglacial marine conditions, or was there a contiguous land-linkage existed between Britain and

64 Ireland, either during, or subsequent to, deglaciation as suggested by GIA simulations (e.g. Lambeck

65 1995)? 
To address this question, and to elucidate the deglacial environments of the Celtic Sea,

67 twelve previously-collected British Geological Survey (BGS) vibrocores (Fig. 1; Table 1) were analysed

68 using a multiproxy litho- and biostratigraphic approach (organic-walled, siliceous, and calcareous

69 microfossils; calcareous macrofossils). A chronological framework is provided by 42 accelerator mass

70 spectrometry (AMS) radiocarbon dates (Table 2). Cores were selected to sample a SW-NE transect

71 across the Celtic Deep Basin (CDB; a bathymetric low on the Celtic Sea shelf; Fig. 1), ideally

72 positioned to test the two competing hypotheses.

73

74

75

\section{Regional Setting}

Lying to the south of St George's Channel, between southern Ireland, southwest Britain, and northwest France, and extending out to the shelf break (Fig. 1), the Celtic Sea occupies some $186,000 \mathrm{~km}^{2}$ of the Northwest European Continental Shelf. Water depths range from 60 to $200 \mathrm{~m}$, the central and northern shelf being generally flat and featureless, the result of bevelling of the inner shelf due to eustatic transgressions and regressions under cool temperate and low arctic Pleistocene conditions (Tappin et al. 1994). In the northern part of the study area, the SW-trending Celtic Deep Basin (CDB) attains water depths of up to $130 \mathrm{~m}$, while the Haig Fras granite batholith shoals to within $40 \mathrm{~m}$ of modern sea-level in the central Celtic Sea. The CDB follows the Caledonian structural trend present in the northern Celtic Sea, modified by glacial erosion since the middle-Pleistocene (Tappin et al. 1994). The northern and central areas also feature linear enclosed deeps $<5 \mathrm{~km}$ wide and $30 \mathrm{~km}$ long, considered to represent jökulhlaup erosion (Wingfield 1989, 1990) or subglacial tunnel-valley formation (Jeffery 1990). In the southern Celtic Sea, the smooth profile of the shelf is interrupted by numerous, generally NW-SE orientated, parallel linear sand ridges (LSR) attaining heights of up to $60 \mathrm{~m}$, lengths of $>200 \mathrm{~km}$, and wavelengths of $10-15 \mathrm{~km}$. The precise origin of these features is disputed (e.g. Praeg et al. 2011) though formation under conditions of lowered eustatic sea-level and high tidal bed shear stress during the Pleistocene appears to be the developing 
91 consensus (Bouysse et al. 1976; Pantin \& Evans 1984; Reynaud et al. 1985, 1999, 2003; Belderson et

92 al. 1986; Marsset et al. 1999; Uehara et al. 2006; Scourse et al. 2009).

93 The northern and central parts of the study area were occupied by grounded glacial ice of

94 the Irish Sea Ice Stream (ISIS) during the Last Glacial Maximum (LGM), marking the southernmost

95 extent of the British - Irish Ice Sheet (BIIS) during this interval (Scourse \& Furze 2001; Sejrup et al.

96 2005; Ó Cofaigh \& Evans 2007; Chiverrell \& Thomas 2010; Fig. 1). Thermoluminescence, radiocarbon,

97 and cosmogenic radionuclide exposure dating of glacially-influenced sediments and landforms in the

98 Isles of Scilly suggests ice retreat from the northern margins of the archipelago 21 ka BP with rapid

99 retreat northwards into the central Irish Sea (Anglesey) under mostly subaqueous conditions in

$100<3000$ years (Scourse 1991a, b; Scourse \& Furze 2001; Hiemstra et al. 2006; van Landeghem et al.

101 2009; McCarroll et al. 2010). The maximal position of the ice margin west of Scilly remains poorly

102 constrained, but the occurrence of over-consolidated diamicton beneath laminated waterlain

103 glacigenic sediments in BGS core 49/-09/044 was used by Scourse et al. (1990, 1991; core CS-3 this

104 study) to infer that the southern limit of the grounded ISIS ice lay near to, but south of, this location

105 (Fig. 1) terminating in a tidewater margin around $49^{\circ} 30^{\prime} \mathrm{N}$ at approximately the modern $135 \mathrm{~m}$

106 isobath. Scourse et al. (1990, 1991; and Scourse \& Furze 2001) suggest the rapid surging advance of

107 a thin ( $100 \mathrm{~m})$ ice lobe across the northern and central Celtic Sea from the BIIS's previously

108 accepted southern margin just south the CDB (Fig. 1). Such thin surging behaviour is supported by

109 evidence from the SE coast of Ireland (Ó Cofaigh \& Evans 2001a, b), ice-streaming in the Irish Sea

110 (Roberts et al. 2007), and limited glacial erosion present in the northern Isles of Scilly (Hiemstra et al.

111 2006; McCarroll et al. 2010). The ISIS tidewater terminus in the central Celtic Sea is considered a

112 significant sediment source for the formation of LSRs, though the exact relationship between LSR

113 development and ice sheet behaviour remains equivocal (Reynaud et al. 1985, 1999, 2003; Marsset

114 et al. 1999; Scourse et al. 2009). Nonetheless, palaeotidal modelling indicates megatidal amplitudes

115 in the Celtic Sea over the deglacial interval with high bed stress leading to significant sediment

116 transport (Scourse et al. 2009). 
117 Late Pleistocene sediments of the Celtic and Irish seas include extensive subglacial and

118 waterlain facies associated with Weichselian ISIS advance and retreat. Multiple tabular Quaternary

119 glacigenic units underlie much of the northern study area with the Upper Till Member of the

120 Cardigan Bay Formation - a stiff clayey diamicton with infrequent shell debris - being interpreted as

121 a late Weichselian lodgement till (Tappin et al. 1994). This is considered to be correlative with the

122 late Devensian Scilly Till (Scourse 1991a). The late Weichselian to early Holocene Western Irish Sea

123 Formation overlies the Cardigan Bay Formation, composed primarily of two facies within the

124 northern Celtic Sea: the Chaotic and Mud facies. The Chaotic Facies is a sandy gravel deposit

125 containing abraded shell debris and is interpreted as a glacimarine or glacilacustrine ice-proximal

126 deglacial unit, whereas the Mud Facies is represented by tabular stratified units of black to grey-

127 green shelly silt with sparse small dropstones and microbiota indicative of cold distal glacimarine

128 conditions (Tappin et al. 1994). Holocene seabed sediments in the northern region are represented

129 by the Surface Sands Formation (Pantin 1977, 1978) divided into an upper member - SL1 (modern

130 marine), conformably overlying the lower SL2 member. SL2 is considered to be a transgressive facies

131 comprising a basal gravel lag and a rich shallow-water temperate fauna. It rests unconformably on,

132 and truncates, underlying Quaternary and pre-Quaternary sediments.

133 Sequences from the central and southern region are more complex. The Melville Formation

134 (Evans 1990) comprises late Weichselian to earliest Holocene shallow marine sands with minor shell

135 and gravel beds and occasional muddy horizons. It is in this formation that the LSR are developed,

136 but it also includes sporadic and discontinuous massive and laminated glacigenic deposits. Core VE

137 49/-09/044 (CS-3 this study), recovered from the flank of one such ridge (Scourse et al. 1990, 1991;

138 this study) shows a laminated waterlain mud conformably overlying a stiff diamicton and was used

139 to help constrain the SW extent of the ISIS. The exact stratigraphic relationship between these

140 sediments and those shelly sands and gravels comprising the LSR from which it was taken remains

141 unclear (Reynaud et al. 2003; Marsset et al. 1999; Scourse et al. 2009; Praeg et al. 2011).

142 Nonetheless, Scourse et al. $(1990,1991)$ defined two glacigenic components of the Melville 
143 Formation: Facies A, the Melville Till, an overconsolidated mud with abundant fine gravel and

144 pebbles and an absent, or infrequent, reworked temperate and arctic macrobiota; and Facies B, the

145 Melville Laminated Clay, conformably overlying Facies A, being a plastic laminated mud with a rich in

146 situ ostracod and exclusively arctic foraminifera. Whereas Facies A, the Melville Till is interpreted as

147 a lodgement till (= Cardigan Bay Formation Upper Till Member in the northern region), Facies B, the

148 Melville Laminated Clay is considered a distal glacimarine facies deposited under shallow quiescent

149 conditions (Scourse et al. 1990, 1991). Both have been interpreted to correlate with late Devensian

150 glacigenic deposits on the Isles of Scilly. However, whilst these interpretations may hold true for the

151 southern Celtic Sea, it should be noted that no paleontological investigation has been undertaken on

152 the critical core VE 49/-09/044 (CS-3) where both facies occur together. Surface sediments in the

153 southern region strongly resemble those in the northern sector, Layers A and B of Evans (1990)

154 being equivalent to SL1 and SL2 (respectively) of the Surface Sands Formation of Pantin (1977, 155 1978).

156 It is these units of the Melville, Cardigan Bay, Western Irish Sea, and Surface Sands

157 formations that form the basis of this study; the glacimarine or glacilacustrine nature of the Melville

158 Laminated Clay/Cardigan Bay Mud Facies being critical in testing the hypothesis of a subaerially-

159 exposed landbridge between Britain and Ireland, south of the CDB, during and subsequent to

160 deglaciation.

161

\section{3. Materials and Methods}

\section{$163 \quad 3.1$ Core materials and lithostratigraphy}

164 Twelve vibrocores collected by the BGS were selected for the present study, constituting a SW-NE

165 transect across the CDB (cores CD-1 to -9 ) and adjacent shelf (cores CS-1 to -3; Fig.1; Table 1), to

166 provide a representative regional modern-to-deglacial stratigraphy (Fig. 2). Cores prove the Western

167 Irish Sea Formation Mud Facies (Tappin et al. 1994) in the northern and central Celtic Sea and the till

168 and laminated clay members of the Melville Formation (Pantin \& Evans 1984; Scourse et al. 1990, 
169 1991) in the central/southern region. Cores were described lithostratigraphically and subsampled for

170 grain size and macro- and microfossils. Grain size analysis comprised oven-drying at low temperature

$171\left(45^{\circ} \mathrm{C}\right)$, weighing, wet-sieving at $63 \mu \mathrm{m}$, oven-drying $\left(45^{\circ} \mathrm{C}\right)$, and subsequent dry-sieving at 63,125 ,

172250,500 , and $1000 \mu \mathrm{m}$, and where necessary at 2, 4, and $8 \mathrm{~mm}$ to calculate $\%$ grain size frequency.

173 Due to the variable degree of desiccation since collection, initial wet weights, water content, and

174 shear strength could not be assessed. Descriptions of two cores (VE 51/-07/199 = CD-7 and VE 49/-

$17509 / 044=$ CS-3) examined for this study have been previously published, including lithostratigraphy

176 and (predominantly) Holocene micropalaeontology for CD-7 (Scourse \& Austin 1994; Austin \&

177 Scourse 1997; Scourse et al. 2002; Marret et al. 2004) and lithostratigraphy for CS-3 (Scourse et al.

178 1990, 1991). Stratigraphic units are numbered from the sea-bed surface down, descriptions being

179 given with the deepest first.

180

\section{$181 \quad 3.2$ Calcareous macro- and microfossils}

182 Samples investigated for calcareous macrofossils (e.g. molluscs) and microfossils (calcareous

183 foraminifera, ostracods) were processed as for grain size analysis (see §3.1). Sample fractions $>500$

$184 \mu \mathrm{m}$ for macrofossil investigation were examined visually and under low-power microscopy. In the

185 majority of samples, all identifiable calcareous macrofossils were picked out. In particularly rich

186 samples, materials were split by micro-splitter. All macrofossil abundances are given as individuals

187 per $100 \mathrm{~g}$ dry sediment (ind./100 g). Macrofossils were identified using Tesch (1947), Tebble (1976),

188 Thompson \& Brown (1976), Graham (1988), and Hayward \& Ryland (1998). Molluscan nomenclature

189 follows Appletans et al. (2011). Calcareous microfossils were noted from subsamples from

190 lithostratigraphic units correlated with the laminated clay and till members of the Melville Formation

191 in an attempt to determine the lacustrine versus marine nature of this unit. Calcareous microfossils

192 were extremely rare (1-2 individuals per dry g of sediment $=$ ind./g), highly abraded, damaged, and

193 generally not identifiable to species level. 
196 Organic-walled microfossils (dinoflagellate cysts = dinocysts, other non-pollen palynomorphs = NPPs,

197 pollen) were examined from laminated clay and till members of the Melville Formation (and

198 Western Irish Sea Formation mud facies). Samples were weighed, oven-dried at low temperature

$199\left(45^{\circ} \mathrm{C}\right)$, weighed, and wet-sieved at $10 \mu \mathrm{m}$ following the addition of Lycopodium clavatum tablets for

200 calculation of concentrations (ind./g). The $>10 \mu \mathrm{m}$ fraction was processed for organic-walled

201 microfossils (Marret \& Zonneveld 2003), encompassing repeated treatments with $10 \%$ cold $\mathrm{HCl}$ and

202 cold $38 \%$ HF acids. Residues were mounted in safranin-stained glycerine jelly and examined

203 systematically under high-power microscopy (x 400). A minimum of 100 dinocysts was counted from

204 each sample wherever possible and any co-occurring NPPs and pollen were noted. Species

205 identifications primarily follow Rochon et al. (1999) and Head et al. (2005). Most dinocysts were

206 identified to species level, with the exception of Brigantedinium spp. (grouped Brigantedinium

207 cariacoense, Brigantedinium simplex, Brigantedinium sp. - cysts without visible/present

208 archaeopyle), Protoperidinium spp. (folded/torn round brown cysts), and Spiniferites spp. Within

209 Spiniferites, an unknown form, Spiniferites sp. 1 was distinguished, whereas spiny brown cysts were

210 tentatively identified as Islandinium minutum?.

211 Several samples from cores CS-3 and CD-1,-2, and-3 were analyzed for diatoms. These were

212 prepared in accordance with standard protocols (Battarbee et al. 2001). Sediments were processed

213 by adding $30 \% \mathrm{H}_{2} \mathrm{O}_{2}$ and heating gently to oxidize organics. Sample dilutions were mounted on

214 microscope slides using Naphrax ${ }^{\mathrm{TM}}$. Identification and enumeration of diatoms was carried out using

215 high-power microscopy (1000x). Taxonomic identification follows Krammer \& Lange-Bertalot (1991,

216 1997). Due to the estimated low amounts of carbonate in these sediments, $\mathrm{HCl}$ was not used in

217 sample preparation. Consequently, infrequent calcareous nanofossils were apparent in examined

218 samples. Furthermore, processing did not remove all organic matter, as evidenced by foraminiferal

219 linings and freshwater algae present in some samples.

220 
222 Forty-two marine molluscan samples were submitted for radiocarbon dating in three discrete

223 batches (Table 2); two batches to the UK Natural Environmental Research Council Radiocarbon

224 Facility - University of Arizona AMS Laboratory (lab code AA), and one batch to the National Ocean

225 Sciences AMS Facility at Woods Hole Oceanographic Institution (lab code OS). Dates were calibrated

226 using CALIB 6.0 (Stuiver et al. 2010) based on the marine calibration dataset Marine09 (Reimer et al.

227 2009). A $\Delta R$ value of $-33 \pm 93$ years (Reimer et al. 2002) for the Late Holocene Celtic Sea and adjacent

228 Irish coast was applied to all dates. Dates are reported in the text as calibrated median probability

229 ages before present (AD 1950).

230

231 4. Results

232 Three regionally-extensive lithostratigraphic units were identified from the examined cores, being

233 encountered throughout the study area. This typical tripartite stratigraphy (Fig. 2) is characterised by

234 a basal sequence of massive to laminated muds (Unit III) marked by small infrequent lonestones and

235 an apparent absence of molluscs. Truncated by a regionally extensive unconformity, this is overlain

236 by bio- and litho-clastic gravels (Unit II) beneath silty sands (Unit I), rich in whole and comminuted

237 marine macrofossils, and comprising the modern seafloor sediments. Variations on this simple

238 tripartite sequence were encountered in several cores (Fig. 2): CD-2 showed an additional unit of

239 gravelly sand (Unit IIla) beneath Unit III laminated muds; CD-3 exhibited thin interbeds of organic-

240 rich laminated silt (Unit Ila) within a particularly extensive sandy gravel sequence considered to be

241 Unit II; CD-8 proved the upper two units (units I and II) underlain by massive shelly and gravelly

242 sands (Unit IIb); CS-3 displayed a massive well-consolidated stony diamicton (Unit IIlb) beneath Unit

243 III.

2454.1 Unit III (laminated-massive mud)

246 4.1.1 Lithostratigraphy 
247 Remarkably uniform across the study area, Unit III is a greyish brown, faintly to well laminated

248 (infrequently massive), sandy to silty clay (Fig. 2). Where well developed, laminae form couplets of

249 silt (to fine sand) and clay approximately $1-2 \mathrm{~mm}$ in thickness. Small (typically $<30 \mathrm{~mm}$ ) subangular

250 to rounded lithic clasts - lonestones - occur in variable concentrations in all cores (CD-8 and -9 do

251 not recover this unit). Unit III varies in thickness from 94 to $475 \mathrm{~cm}$ from the upper erosional contact

252 with Unit II to the core base. In only two instances (CD-2, CS-3) are sediments beneath typical Unit III

253 muds penetrated (Fig. 2). In CD-2, a poorly sorted gravelly sand containing clay and lithic clasts and

254 highly abraded bioclastic debris (Unit IIla) occurs below the laminated mud. In CS-3, a $15 \mathrm{~cm}$ thick

255 subunit (Unit IIIb) of overconsolidated clast-rich diamicton, previously described by Scourse et al.

256 (1990) as a lodgement till, occurs at the core base beneath Unit III.

257

258 4.1.2 Biostratigraphy

259 In stark contrast to units I and II, Unit III is marked by the near-absence of identifiable macrofossils

260 (Fig. 3). Notably, macrofossil fauna identified from the very top of Unit III (CD-5, 070-075 cm)

261 represent burrow infill and interstitial breccia matrix derived from the overlying Unit II sandy gravels

262 and is thus not considered in situ. CD-2 $237-242 \mathrm{~cm}$ contained exceptionally rare identifiable

263 macrofossil materials (one heavily abraded bryzoan fragment, two balanoid plates) considered not

264 to be contamination from overlying units. In CD-2, a poorly sorted gravelly sand (Unit Illa), occurring

265 beneath Unit III, contained infrequent extremely abraded bioclastic fragments ( 0.44 ind./100 g;

266 including barnacle plates, bryzoan fragments, extremely rare echinoid spines, and a single abraded

267 valve of Nucula sp.; no microfossil assay conducted). No macrofossils were evident in the basal

268 diamicton (Unit IIIb) from CS-3, however Scourse et al. (1990) assign this subunit to Facies A of the

269 Melville Till from which rare abraded, broken temperate and arctic macrofossils have been recorded

270 (Hiatella sp. and balanoid plates, considered reworked; Scourse et al. 1990).

271 Four Unit III samples from CDB cores CD-1, -2 , and -3 and the open shelf core CS-3 were

272 investigated for siliceous microfossils. These showed exceptionally rare freshwater diatoms, though 
273 observed numbers (1-12 valves) were insufficient to warrant meaningful statistical counts. One

274 sample (CD-3) proved barren of diatoms. The common planktonic diatom Aulacoseira distans, and

275 the widely distributed and exclusively freshwater epipelic diatom Neidium ampliatum was observed

276 with good preservation, whereas a large fragment of the epipelic freshwater diatom Pinnularia

277 microstauron occurred in one sample (CD-1). No marine diatoms, in whole or fragments, were

278 observed in any of the investigated samples. Other microfossils present in diatom slides include

279 siliceous stomatocyst of the freshwater algae Chrysophyceae, and organic microfossils such as

280 Botryococcus, Pediastrum, and foraminiferal linings. External calcified plates (coccoliths) from

281 calcareous marine nanoplankton (Prymnesiophyta) were observed in all samples consistent with

282 their reworking from Cretaceous chalk outcrops on the floor of the Celtic and Irish seas (Evans 1990;

283 Scourse et al. 1990; Tappin et al. 1994). No meaningful differences in the diatom assemblages were

284 evidenced between the CDB and open shelf Unit III samples.

285 Dinocyst abundances are low in Unit III, with most samples exhibiting concentrations $<650$

286 cysts/g and diversities of $<10$ species (max. 18 species; Fig. 4A). Only one sample (CD-7) shows

287 conspicuously high dinocyst abundances, reaching $\sim 2780$ cysts/g. Dinocyst assemblages are

288 overwhelmingly dominated by phototrophic taxa, in particular Bitectatodinium tepikiense whose

289 relative abundances typically reach $>40 \%$. This species is accompanied by lesser proportions of

290 Lingulodinium macherophorum and Operculodinium centrocarpum, as well as Spiniferites spp.

291 (Spiniferites lazus, Spiniferites cf. membranaceus) and Islandinium minutum?. Brigantedinium spp.

292 and other protoperidinoid dinocysts are much reduced and only present in noticeable amounts in

293 samples from CS-3. Absolute abundances of acritarchs and zoomorphs are much reduced in Unit III

294 (Fig. 4B). Foraminiferal lining concentrations are particularly low (<35 ind./g), apart from one,

295 potentially contaminated sample at the Unit II/Unit III transition (CD-2, $190 \mathrm{~cm})$. Invertebrate eggs

296 and, in particular, invertebrate mouthparts are also much reduced or absent in Unit III. In contrast,

297 freshwater chlorophycean algae (Botryococcus, Pediastrum) are present in most Unit III samples in

298 variable amounts. Corylus pollen concentrations are low whereas Pinus pollen and Pteridium spores 
299 show variable absolute abundances, sometimes outnumbering Unit II values (Fig. 4B).

300 Concentrations of pre-Quaternary materials such as dinocysts (e.g. Achomosphaera andalousiensis)

301 and spores are high. Unit III samples from the open shelf (CS-3) show similar dinocyst abundances

302 and assemblage structures to those from within the CDB, although Brigantedinium spp. are elevated

303 and Spiniferites spp. appear reduced (Fig. 4A). Three samples from the Unit IIIb basal diamicton in

304 CS-3 (Fig. 4A; Facies A - Melville Till of the Melville Formation sensu Scourse et al. 1990), below the

305 typical Unit III laminated muds, show extremely rare dinocysts or are barren. Where present,

306 dinocysts exhibit exceptionally low concentrations and diversities. Nonetheless, similar to typical

307 Unit III deposits, a mixture of cool-temperate and cosmopolitan taxa occurs. Though markedly

308 impoverished, these Unit IIIb diamicton populations nevertheless closely resemble some dinocyst

309 assemblages from typical Unit III laminated mud samples. Other organic-walled microfossils are

310 generally absent in the diamicton, apart from sporadic occurrences at very low concentrations

311 (foraminiferal linings, invertebrate eggs, Botryococcus, pollen; Fig. 4B). It should be noted that

312 Scourse et al. (1990) consider this diamicton to be a subglacial deposit, thus inferring that all

313 included microfossils should be reworked.

\section{4.1.3 Chronology}

316 No dates are available from Unit III due to the absence of dateable in situ organic materials. The

317 oldest date from the overlying Unit II of 13.9 cal ka BP (CD-8, S. elliptica, AA-36251; Table 2) provides

318 a minimum age on the deposition of Unit III. If the Unit IIIb basal diamicton present below Unit III in

319 CS-3 is considered a lodgement till correlative and coeval with the Scilly Till (sensu Scourse et al.

320 1990), an approximate maximum age of 21-22 cal ka BP (McCarroll et al. 2010) for Unit III deposition

321 can be inferred.

322

$323 \quad 4.2$ Unit II (bioclastic gravel)

324 4.2.1 Lithostratigraphy 
325 Unit II, occurring in all cores, is typically a massive, silty sandy gravel, frequently upward fining (Fig.

326 2). Whole shells and fragments are common throughout, increasing upwards. The lithic component

327 includes rounded to subrounded gravel-sized clasts ( $\sim-20 \mathrm{~mm}$ in size). In all cases, Unit II rests

328 unconformably on underlying materials, with an erosional surface marked by brecciation and

329 bioturbation. Clay clasts derived from erosion of underlying Unit III are frequent towards the base of

330 Unit II. Iron and manganese staining around lithic and biogenic clasts is also common towards the

331 unit base. Unit thicknesses are variable $(8-264 \mathrm{~cm})$, as are colours, though greyish brown to olive

332 yellow is typical.

333 In two cores (CD-1 and -3) Unit II is interrupted by thin $(<20 \mathrm{~cm})$ sandy silt interbeds (Unit Ila;

334 Fig. 2). In CD-1 this single interbed is massive and shell-rich whilst the three interbeds in Unit II CD-3

335 are laminated, apparently organic-rich, and dark in colour. An additional variation (Unit Illb) is noted

336 from CD-8 (Fig. 2), where massive sand (>85 cm thick) unconformably underlies the typical Unit II

337 sequence. These sands are gravelly towards the base, containing blackened lithic and shell clasts,

338 and clay balls, but fine upward into a clean and well sorted sand with little to no silt.

\subsubsection{Biostratigraphy}

Macrofossil assemblages from Unit II are broadly similar to Unit I (Fig. 3). Species diversities are high

342 (18-47; typically >30), populations dominated by subtidal boreal-temperate taxa typical of sandy

343 substrates. As in Unit I, bivalves dominate (max. 483 ind./100 g, CS-1) with prosobranch gastropods

344 (max. 90 ind./100 g, CD-1) and echinoderms (max. 182 ind./100 g, CD-1). Dominant species include

345 bivalves A. ephippium, P. ovale, and T. ovata, and the echinoderm E. pusillus. Though present in Unit

346 I, high numbers of the bivalve S. elliptica and the prosobranch gastropod Gibbula tumida

347 characterise Unit II, along with high concentrations of serpulid polychaete material (common species

348 including Pomatoceros triqueter and Ditrupa arietina) and calcareous bryzoan debris. Abundant

349 balanoid plates (max. 372 per 100 g, CD-9) frequently outnumber echinoderm spicules (max. 163 per

$350100 \mathrm{~g}, \mathrm{CD}-2)$. In contrast to Unit I, infrequent small (1-5 mm) prosobranch gastropods with intertidal, 
351 or restricted low water spring tide to shallow subtidal affinities (Graham 1988; Peacock 1993) occur

352 in the majority of Unit II samples (max. 19 ind./100 g, CD-9). These include Rissoa parva, Rissoella

353 opalina, Pusillina sarsi, Tornus subcarinatus, and Cingula cingillus. Silty interbeds (Unit II a; CD-1 and

$354-3$ ) and underlying massive sands (Unit IIb; CD-8) possess macrofossil assemblages similar to those in

355 more typical Unit II deposits, but display much lower species diversities ( $<10$ taxa) and

356 concentrations (max. 39 ind./100 g, CD-3; Fig. 3).

357 Dinocyst data are only available from Unit lla (Fig. 4A) interbeds present in CD-3, not from

358 the more typical silty sands and gravels of Unit II widespread through the CDB (see Marret et al.

3592004 for typical Unit II dinocyst records; CD-7). These specific samples were taken to elucidate the

360 palaeoenvironmental origin and the intertidal/ estuarine vs. deeper marine character of these

361 interbeds. Dinocyst concentrations in these samples are generally low ( $150-560$ ind./g), diversities

362 ranging from 12 to 23 species. Assemblages are predominantly composed of protoperidinoid taxa,

363 including Protoperidinium spp., Quinquecuspis concreta, and Votadinium calvum. These

364 heterotrophs are accompanied by phototrophic Spiniferites spp. (including Spiniferites sp. 1 and

365 Spiniferites cf. membranaceus). Other NPPs (Fig. 4B), including invertebrate remains (eggs,

366 mouthparts), foraminiferal linings, and freshwater algae are present in low to moderate amounts.

367 Corylus and Pinus pollen are abundant, whereas pre-Quaternary dinocysts and spores are rare (both

$368<20$ ind./g; Fig. 4B).

369

$370 \quad$ 4.2.3 Chronology

371 Excluding deposit-feeding bivalves (e.g. Nucula spp.), which may exhibit exaggerated ages due to

372 uptake of "old" carbonate depleted in ${ }^{14} \mathrm{C}$ ("Portlandia Effect" sensu England et al. 2012), dates from

373 Unit II span a wide range of ages, from 4.0 to 13.9 cal ka BP. We exclude a date of 0.4 cal ka BP (CS-1,

374 Corbula gibba, AA-36188; Table 2) considered anomalously young relative to other dates from this

375 horizon. Age inversions and wide age spreads within the same horizon are frequent. For example,

376 CD-4 where dates of 10.3 cal ka BP (OS-79220) and $6.7 \mathrm{cal} \mathrm{ka} \mathrm{BP} \mathrm{(AA-32278)} \mathrm{occur} \mathrm{at} \mathrm{the} \mathrm{same}$ 
377 sample depth, and CD-3 with a date of 10.9 cal ka BP (AA-36242) above dates of 9.3 to $10.0 \mathrm{cal}$ ka BP

378 (AA-36243; AA-36244; OS-79103; Table 2). Nonetheless, the majority of accepted dates (20) are >9

379 cal ka BP, with seven dates being $\geq 12.7$ cal ka BP. Of these seven older dates, five occur within the

380 massive shelly sands (Unit IIb) underlying Unit II in CD-8, including the oldest dates (13.9 cal ka BP;

381 OS-79120 and AA-36251) encountered in this study. Previously published dates from CD-7 (Scourse

382 \& Austin 1994; 9.4 and 13.1 cal ka BP) agree with this general chronology.

383 Out of the total accepted 31 dates from Unit II (including Ila and IIb), seven were derived

384 from obligate intertidal to shallow water taxa (Table 2). These seven dates span the entire age range

385 encountered for Unit II though over half are $\geq 12.7 \mathrm{cal}$ ka BP. Such intertidal taxa dates should be

386 viewed with caution, as all from within the CDB must be considered redeposited given their

387 occurrence in a bathymetric basin that could not have been subjected to intertidal conditions during

388 late Pleistocene - early Holocene lower sea-levels. As a basin, the CDB would have either formed a

389 subtidal (glaci)marine embayment or an isolated lacustrine system under such conditions (see §5.2).

390

$391 \quad 4.3$ Unit I (upper silty sand)

392 4.3.1 Lithostratigraphy

393 Unit I is a predominantly an upward-fining massive silty sand with infrequent finer silty interbeds in

394 some cores (CD-2 and -9). Thickness varies from 10 to $195 \mathrm{~cm}$, whilst colour ranges from olive grey

395 to brownish grey. Contact with underlying Unit II is typically gradational although some cores (CD-1,

$396-4,-8)$ show an abrupt transition. Throughout the area, Unit I is exceptionally rich in bioclastic

397 material, constituting the modern seabed sediment.

398

399 4.3.2 Biostratigraphy

400 Calcareous marine macrofossils are universally abundant (Fig. 3), with a maximum of 39 species per

401 individual sample (CD-4, 50-55 cm). Although variations are apparent, assemblages are typically

402 dominated by the bivalves Anomia ephippium, Parvicardium ovale, and Timoclea ovata, 
403 accompanied by the prosobranch gastropod Turritella communis and the clypeasteroid echinoderm

404 Echinocyamus pusillus. Bivalves such as Spisula elliptica, Hiatella arctica and Nucula sulcata also

405 occur frequently. Bivalve concentrations reach a maximum of 2314 ind./100 g (CD-4) whereas

406 prosobranch gastropods are less abundant (max. 133 ind./100 g, CD-2). Large quantities of

407 unidentified echinoderm spicules (max. 1160 ind./100 g) and barnacle (balanoid) plates (max. 515

408 /100 g) typify most samples, as do infrequent fish otoliths (likely from Trisopterus minutus). In some

409 samples (CD-5) shell fragments and byssus threads of the fan mussel Atrina fragilis occur in notable

410 quantities. The thecosomat pteropod Limacina retroversa is also locally abundant (CD-4 and -2; 312

411 and 227 ind./100 g, respectively).

412

$413 \quad$ 4.3.3 Chronology

414 The few direct dates available from Unit I (Table 2) indicate an early to mid Holocene

415 commencement of deposition. Chronology is further constrained by numerous dates from

416 underlying Unit II (see §4.2.3), suggesting asynchronous onset of Unit I deposition throughout the

417 region. Previously published molluscan and bulk benthic foraminiferal dates from Unit I in CD-7

418 (Scourse \& Austin 1994; Scourse et al. 2002) range from $\sim 8$ to 3 cal ka BP, in agreement with

419 chronologies described in the present study.

420

421 5. Interpretations and Discussion

$422 \quad 5.1$ Interpretation of units

423 The shallow stratigraphy of the CDB and adjacent shelf documents the terminal Pleistocene to

424 Holocene palaeoenvironmental evolution of the Celtic Sea. Typically, short $(<6 \mathrm{~m})$ vibrocores prove

425 three lithostratigraphic units (Fig. 2): (i) an upper shelly silty sand deposit (Unit I) constituting

426 modern seabed sediments and containing a rich cool-temperate marine macrofauna, resting

427 conformably on (ii) a regionally extensive gravel lag (Unit II), itself containing abundant boreal-

428 temperate marine macro- and microfossils. The majority of cores also prove (iii) a waterlain massive 
to laminated glacially-influenced mud unit (Unit III) marked by infrequent small lonestones,

430 interpreted as dropstones; an absence of macrofossils, calcareous microfossils, and marine diatoms;

431 and low-abundance and disparate palynomorph assemblages. Unit III is truncated by an extensive

432 erosional surface over which Unit II occurs. Rarely, cores prove deposits beneath Unit III, including

433 glacial diamicton (Unit IIIb; CS-3) and a poorly sorted gravelly sand (Unit IIla; CD-2).

434 Unit I is considered equivalent to SL1 (in the north) and Layer A (central and south), whilst

435 Unit II equates to SL2 (Tappin et al. 1994) and Layer B (Evans 1990). The glacigenic waterlain muds of

436 Unit III are correlative with the Western Irish Sea Formation Mud Facies (Tappin et al. 1994) and the

437 Laminated Clay of the Melville Formation (Pantin \& Evans 1984; Evans 1990; Scourse et al. 1990).

438 The Unit IIIb diamicton at the base of CS-3 has previously been assigned to the southern region

439 Melville Till of the Melville Formation (Scourse et al. 1990, 1991), equivalent to the Upper Till

440 Member of the Cardigan Bay Formation (Scourse 1991a; Tappin et al. 1994). Although limited core

441 penetration restricts the interpretation of the Unit Illa gravelly sand at the base of CD-2, its

442 relationship to overlying units suggests a correlation with the Chaotic Facies of the Western Irish Sea

443 Formation. (Tappin et al. 1994).

\subsubsection{Unit III}

446 Lithostratigraphically, the laminated muds of Unit III represent glacially-influenced waterlain

447 sediments deposited predominantly from suspension, with a minor component of small ice-rafted

448 dropstones. Similar deposits have been recorded from deglacial glacimarine and glacilacustrine

449 settings boarding the Celtic and Irish seas (Fletcher \& Siddle 1998; Hambrey et al. 2001; Thomas et

450 al. 2004; Etienne et al. 2006) and from numerous other locations including the deglacial margins of

451 the Laurentide Ice Sheet (e.g. Freeman-Lynde et al. 1980; Kerr 1987; MacLean et al. 1989; Andrews

452 et al. 1991; Pieńkowski et al. 2012). Deposition under highly turbid, quiescent, low energy conditions

453 and an absence of bioturbation is evidenced by the frequently laminated nature of this unit (Syvitski

454 1991; Ó Cofaigh \& Dowdeswell 2001). Though clearly "glaciaqueous", the lithostratigraphy alone 
455 (this study) is insufficient to conclusively distinguish between marine or lacustrine conditions.

456 Nonetheless, given the regional uniformity of this unit and its occurrence in the previously described

457 CS-3, it is considered synonymous with Facies B and the Melville Laminated Clay of the Melville

458 Formation of Scourse et al. (1990). Notably, the Melville Laminated Clay is considered glacimarine,

459 defined from southern Celtic Sea BGS cores, with rich, in situ arctic ostracods, foraminifera, and

460 molluscs (Scourse et al. 1990).

461 In marked contrast to previously described Melville Laminated Clay samples (Scourse et al.

462 1990), Unit III samples examined in this study are characterised by an absence of identifiable

463 macrofossils (Fig. 3), apart from one sample (CD-2) containing extremely sparse and highly abraded

464 biogenic fragments possibly glacially reworked from earlier marine sediments. Similarly, microfossils

465 are generally sparse. Only extremely rare freshwater diatoms are recorded, whereas marine diatoms

466 are absent. Organic-walled microfossils (Fig. 4) typically exhibit low dinocyst concentrations and a

467 near-absence of other NPPs, especially foraminiferal linings. Dinocyst assemblage structures also

468 differ compared to studied Unit II interbeds, phototrophs dominating over heterotrophs. The

469 principal Unit III dinocyst B. tepikiense is indicative of fully marine, temperate-polar conditions. It

470 predominantly dwells in regions with seasonal sea-ice cover of $<4$ months/year and summer sea-

471 surface temperatures (SST) of $10-20^{\circ} \mathrm{C}$ (Marret \& Zonneveld 2003), including waters off Iceland, the

472 Faroe Islands, and the east coast of Canada (Harland 1983; Mudie 1992; Matthiessen et al. 2005). In

473 the modern Celtic Sea, B. tepikiense is characteristic of cool, stratified regions (Marret \& Scourse

474 2002; cf. Marret et al. 2004), but never reaches relative abundances of $>5 \%$, in marked contrast to

475 its dominance in Unit III. B. tepikiense is furthermore prominent in Late Glacial Interstadial

476 sediments of the NW European continental margin (Harland 1994). Of the two other prominent

477 dinocyst taxa in Unit III, O. centrocarpum is cosmopolitan, tolerant of large fluctuations in physical

478 parameters (including sea-ice), and abundant in the cold to temperate North Atlantic, whereas $L$.

479 macherophorum prefers temperate to tropical regions with SST of $>10^{\circ} \mathrm{C}$. Its highest abundances are

480 reported from coastal waters off NW Africa and the Iberian Peninsula (Marret \& Zonneveld 2003). In 
481 general, the dinocyst assemblages in Unit III indicate cool to temperate marine conditions, but show

482 a mixture of both fully coastal/marine (B. tepikiense, S. membranaceus, S. lazus) and brackish water-

483 tolerant (S. ramosus), sea-ice tolerant (B. tepikiense, O. centrocarpum, Selenopemphix quanta,

484 Islandinium minutum) and intolerant (L. macherophorum, S. membranaceus), and temperate-polar

485 (B. tepikiense) as well as thermophilic (S. mirabilis) taxa (Marret \& Zonneveld 2003). The overall cool

486 to temperate character of this assemblage is inconsistent with the demonstrably glacially-influenced

487 sediments. The occurrence of sea-ice-intolerant and thermophilic dinocysts and the relatively high

488 species diversity is particularly problematic, and thus points to a notable reworked component.

Furthermore, the paucity of other NPPs, especially zoomorphs, is striking. The presence of such palynomorphs should be expected in glacimarine sediments, even at times of adverse, ice-proximal conditions (e.g. Mudie et al. 2006; Pieńkowski et al. 2012).

It has been suggested that such mixed dinocyst assemblages resemble those from modern temperate saltmarsh and estuarine environments, such as the Humber Estuary (Marret pers. obs.) and the Massachusetts coast (Pospelova et al. 2004, 2005). However, despite the occurrence of common taxa such as $O$. centrocarpum, Spiniferites spp., L. macherophorum and I. minutum both in Unit III and reported estuarine samples (Pospelova et al. 2004, 2005), the foremost taxon present in Unit III, B. tepikiense, is absent. Critically, the laminated and dropstone-rich glacially-influenced sediments and the near-complete absence of any marine/estuarine macrofossils, foraminifera, ostracods, and diatoms strongly argue against an estuarine origin for Unit III deposits.

In summary, Unit III is a waterlain distal glaciaqueous deposit containing an exceptionally sparse reworked macrofossil assemblage and lacking key in situ marine indicators such as foraminifera, ostracods, and diatoms. If organic-walled microfossils are assumed to be entirely (or to a large extent) in situ, the cool-temperate palaeoenvironmental conditions they indicate appear at odds with the remainder of the evidence. These inconsistencies preclude a simple palaeoenvironmental interpretation of this unit. Rather, two hypotheses are proposed: firstly, that Unit III represents a shallow ice-distal glacimarine facies with a general absence of in situ flora and 
507 fauna, aside from the sea-ice and brackish-water tolerant dinocyst component (which itself may also

508 be reworked). Secondly, Unit III represents a glacilacustrine facies, wherein all marine macro- and

509 microfossils, including the dinocyst component are glacially (and/or glacifluvially) reworked from

510 pre-existing temperate, boreal, and arctic marine deposits during deglaciation.

511

$512 \quad 5.1 .2$ Unit II

513 Unit II of the central and northern Celtic Sea is interpreted as a regionally extensive lithic and

514 bioclastic lag associated with an unconformity truncating underlying basal laminated muds of Unit III

515 (or other pre-Holocene sediments), above which it occurs. Oldest dates from Unit II provide a

516 minimum age for the onset of lag generation of $13.9 \mathrm{cal} \mathrm{ka}$ BP. This indicates commencement of

517 widespread erosion across the continental shelf associated with rising late Weichselian to early

518 Holocene sea-levels. Sedimentology and macrofossil biostratigraphy suggest a highly productive

519 shallow subtidal marine environment marked by storm-wave and current re-suspension (Peacock

520 1993; Wingfield 1996; Kidwell 1998, 2002), its typical upward-fining nature and gradation into the

521 overlying silty sands of Unit I consistent with increasing Holocene water depths. Radiocarbon dates

522 from Unit II span much of the early to mid Holocene (Table 2), with apparent age inversions and

523 wide ranges of dates from the same depth intervals suggesting considerable time-averaging,

524 condensation, and sediment starvation - conditions expected in a shallow high-energy environment

525 (Fürsich \& Aberhan 1990; Kowalewski et al. 1998; Kidwell 1998, 2002).

526 Macrofaunas are typically subtidal boreal to temperate, taxa currently encountered on the

527 NW European continental shelf (Tebble 1976; Graham 1988; Hayward \& Ryland 1998). Organic-

528 walled microfossils from interbed samples (CD-3) show dinocysts typical of the NW European

529 continental shelf dominated by temperate taxa (Fig. 4A; Dodge \& Harland 1991; Marret \& Scourse

530 2002), including protoperidinoids such as $Q$. concreta and V. calvum, also present in the modern-

531 day, seasonally stratified sector of the Celtic Sea (Marret \& Scourse 2002). Round brown cysts

532 (Protoperidinium spp., Brigantedinium spp.) produced by several motile dinoflagellate species, are 
533 also prominent in this unit. These have been shown to occur in high abundances in regions of

534 enhanced productivity (Marret \& Zonneveld 2003). Species of the genus Spiniferites, also abundant

535 in Unit II, have been found in high numbers along the modern British coastline (Reid, 1975). Unlike

536 modern populations in the Celtic Sea (Marret \& Scourse 2002), dinocysts concentrations from Unit II

537 are low, however this may be a function of the coarse nature of the sediment and shallow turbulent

538 conditions preventing cyst deposition as opposed to reflecting in situ productivity. It should be noted

539 that these microfossil samples are from interbeds only, and thus may not be representative of

540 "typical" Unit II sandy gravels. However, macrofossil concentrations from Unit Ila interbeds are also

541 markedly low relative to typical Unit II deposits. Nonetheless, both dinocyst assemblages and

542 concentrations in Unit lla closely resemble those previously described from Unit II (CD-7, Marret et

543 al. 2004). Although no comparable NPP data are available from the study area, the presence of

544 foraminiferal linings, invertebrate remains, and other palynomorphs in Unit II (Fig. 4B) is comparable

545 to other marine settings (e.g. de Vernal et al. 1992; McCarthy et al. 2003), supporting dinocyst-based

546 interpretations.

547 The presence of infrequent small obligate intertidal and shallow water prosobranch

548 gastropods is inconsistent with CDB physiography, where either subtidal marine or lacustrine

549 conditions should have persisted following deglaciation (Eyles \& McCabe 1989, 1991; Lambeck 1991,

550 1993, 1995, 1996; Lambeck \& Purcell 2001; Scourse \& Furze 2001; Uehara et al. 2006). This material

551 is considered allochthonous, advected into the CDB from nearby intertidal areas by stormwave and

552 tidal currents. High tidally-driven bottom current velocities resulting in post mortem transport and

553 selective destruction is also indicated by benthic foraminifera previously described from this unit

554 (CD-7, foram zone F1b, Scourse et al. 2002) and supported by palaeotidal simulations of bed stress

555 evolution (Scourse et al. 2009). Despite the possibility of intertidal conditions on the higher

556 continental shelf following deglaciation (Lambeck 1991, 1993, 1995, 1996; Lambeck \& Purcell 2001),

557 macrofaunas from Unit II do not conclusively indicate such an environment. Indeed, fewer obligate

558 intertidal individuals are found in open shelf samples from Unit II than within the CDB, macrofaunas 
559 being almost universally composed of subtidal taxa (Fig. 3). If the littoral zone did progress across

560 the central Celtic Sea shelf during rising late glacial and Holocene sea-levels, no definitive in situ

561 deposits have been identified in this study.

562

$563 \quad 5.1 .3$ Unit I

564 Unit I represents a boreal-temperate subtidal shelf sea deposit recording increasing water depths

565 throughout the Holocene. Some cores (CD-1 and -3) show possible truncation at the top of Unit I, a

566 phenomenon also recorded from CD-7 (Austin \& Scourse 1997; Scourse et al. 2002). Furthermore, it

567 is from this unit CD-7 (Unit I this study; “Lithozone 3" sensu Scourse et al. 2002; "Lithozone 1" sensu

568 Marret et al. 2004) that the onset of Celtic Sea seasonal stratification as a function of increasing

569 water depth has been described on the basis of foraminifera and dinocysts (Scourse \& Austin 1994;

570 Austin \& Scourse 1997; Marret et al. 2004), a threshold change from mixed to stratified watermasses

571 that occurred between 8990 and 8440 cal yr cal BP (Scourse et al. 2002). This environmental shift in

572 Unit I is confirmed by the occurrence of the pteropod L. retroversa - a planktonic species associated

573 with cool boreal, stratified waters (Bathman et al. 1991; Gallager et al. 1996; Gowen et al. 1998).

574 Where present (CS-3, CD-2, CD-4), high L. retroversa numbers are achieved after the establishment

575 of seasonal stratification. Its decline in the late Holocene is likely a function of increased water

576 temperatures rather than a breakdown in seasonal stratification. Molluscan (and other) macrofossils

577 are all subtidal and of boreal to temperate affinities, found on the modern NW European continental

578 shelf (Tebble 1976; Thompson \& Brown 1976; Graham 1988; Hayward \& Ryland 1998).

579

$580 \quad 5.2$ Competing hypotheses

581 The clay-rich and frequently laminated sediments of Unit III, marked by sporadic small dropstones,

582 suggest distal, glacially-influenced subaqueous suspension-driven deposition with a minor seasonal

583 ice or iceberg-driven rafted component. However, the marine or lacustrine nature of such an

584 environment is difficult to ascertain especially considering the contradictory nature of the contained 
585 microfossil assemblages and absence of macrofossils. It is on this unit, however, that a glacimarine

586 or a glacilacustrine interpretation hinges.

587 A temperate estuarine and saltmarsh origin for the Celtic Sea laminated clay sequences (Unit

588 III) can be discounted on litho- and bio-stratigraphic grounds (see §5.1.1 above). Furthermore, a fully

589 glacimarine origin (deep water, full salinities) is unlikely given the absence of critical in situ macro-

590 and micro-fossils. Barren glacimarine sediments have been recorded from several modern tidewater

591 glacier and fjord delta settings in Alaska and Greenland (e.g. Cowan \& Powell 1990; Gilbert et al.

592 1998, 2002; Desloges et al. 2002) where high sedimentation rates prevent the establishment of

593 benthic communities (Korsun \& Hald 1998; Jaeger \& Nittrouer 1999). In all such cases, however, a

594 steep environmental gradient exists from immediately proximal to more distal settings; bioturbated

595 sediments being encountered within only four kilometres of the ice front or fjord head. Nor should

596 planktonic material be excluded from deposition in such settings, especially where tidal pumping is

597 significant (Cowan et al. 1998, 1999; Gilbert et al. 2002). Indeed, ice-proximal sediments including

598 water-lain diamictons and laminated sequences from the deglacial Barents Sea (Murdmaa et al.

599 2006) and the Canadian High Arctic (Pieńkowski et al. 2012), where rapid deposition from sediment

600 plumes can be inferred, are nonetheless marked by a sparse but recognizable in situ glacimarine

601 microbiota. In the Celtic Sea, in situ arctic and glacimarine species have been noted from the south

602 where they occur in lithostratigraphically similar units (Melville Laminated Clay; Scourse et al. 1990)

603 to Unit III. Fauna reported by Scourse et al. (1990) include ostracods (Rabilimis mirabilis, Krithe

604 glacialis, Cytheropteron montrosiense), abundant foraminifera (Islandiella helenae, Islandiella

605 is/andica) and the boreo-arctic mollusc Yoldiella fraterna. These definitive glacimarine indicators all

606 occur south of the postulated LGM southern maximum for the BIIS on the Celtic Sea shelf, laminated

607 and massive clays north of the ice limit (Unit III this study) being effectively barren of macrofossils,

608 foraminifera, and marine diatoms, and containing ecologically incompatible palynomorphs. Whilst

609 the transition from fossil-rich sediments in the south to near-barren in the central and northern

610 Celtic Sea may indeed reflect a steep glacimarine environmental gradient, the spatial consistency of 
611 Unit III laminated muds both within and between cores may challenge this interpretation.

612 Furthermore, the absence of any successional changes in Unit III micro- or macrobiota that could be

613 expected during progressive northward ice retreat from the Celtic and Irish seas is also problematic.

614 Two competing hypotheses thus remain that can be invoked to explain the formation of the

615 Unit III laminated clays present in the CDB and across the broader northern and central shelf of the

616 Celtic Sea: a low sea-level model with deposition of such laminated sequences in a glacilacustrine

617 system impounded within the CDB and in other smaller satellite water bodies on a subaerially

618 exposed shelf; or a higher sea-level model with deposition of fine grained sediments in a broad

619 shallow glacimarine embayment, where very high sedimentation rates effectively prevent primary

620 production.

621

\section{5.2.1 The glacilacustrine hypothesis}

623 In this scenario, low relative sea-level in the central Celtic Sea (Lambeck 1991, 1993, 1995, 1996;

624 Lambeck \& Purcell 2001; Uehara et al. 2006) results in sufficient continental shelf exposure during

625 and subsequent to deglaciation to isolate the CDB and other bathymetric lows from the North

626 Atlantic. Rapid sediment plume deposition and iceberg rafting associated with the northward retreat

627 of the ice margin results in emplacement of massive and laminated mud sequences with a minor

628 dropstone component (Unit III). In situ productivity within the glacilacustrine system is inhibited due

629 to high turbidity, rapid sediment accumulation rates, and low temperatures (Korsun \& Hald 1998;

630 Jaeger \& Nittrouer 1999). Thus, aside from an extremely sparse freshwater diatom component, all

631 biota noted from Unit III are glacially reworked from older temperate to glacimarine sediments

632 overridden by the ISIS. Water depths within such a postulated CDB lake would have been shallow,

633 not exceeding $30 \mathrm{~m}$ (based on modern bathymetry) whilst the rhythmicity seen in some of the Unit

634 III muds would be a function of variable sediment and meltwater input events (Cowan et al. 1999; Ó

635 Cofaigh \& Dowdeswell 2001). The extent of such a glacilacustrine system is hard to determine, but

636 would have occupied the CDB and could have conceivably extended through St George's Channel in 
637 to the Irish Sea in contact with a rapidly retreating ice margin. Separate or connected lesser lake

638 basins would also have occurred on the exposed shelf within the ISIS ice limit. Assuming lake

639 isolation and shelf exposure during ice retreat, lacustrine conditions would have persisted from 21-

64022 cal ka BP (assuming Celtic Sea and Isles of Scilly ice maxima are coeval; McCarroll et al. 2010) until

641 the reconnection with the North Atlantic due to the eustatically-driven transgression sometime prior

642 to 13.9 cal ka BP. With the establishment of marine conditions, tidal current and stormwave erosion

643 and winnowing of Unit III glacilacustrine sediments would have been significant (Uehara et al. 2006;

644 Neill et al. 2009; Scourse et al. 2009). Wingfield (1996) estimates that up to $15 \mathrm{~m}$ of stony

645 glacimarine/glacilacustrine muddy sediment may be lost before a sufficient armouring lag of

646 winnowed dropstones and accumulated molluscan fragments (Unit II) develops that inhibits further

647 erosion.

648

$649 \quad$ 5.2.2 The glacimarine hypothesis

650 Assuming the retreat of the ISIS from the Celtic Sea shelf in a tidewater setting, the CDB and

651 adjacent shelf would have formed a shallow (maximum 30-40 m given modern bathymetry and

652 elevation of southern sill; Peltier et al. 2002), broad glacimarine embayment fed by meltwater from

653 the retreating ice margin characterized by direct iceberg calving. As in the glacilacustrine hypothesis,

654 exceptionally high sedimentation rates can be expected, with fine-grained deposition from sediment

655 plumes and minor dropstone rafting. Rates of 5-10 $\mathrm{mm}$ per annum have been reported for modern

656 fjords (Cowan and Powell 1991; Gilbert et al. 1998; Desloges et al. 2002) with extreme rates of >4

$657 \mathrm{~mm}$ per day recorded in systems influenced by surging glaciers (Gilbert et al. 2002). As in the

658 glacilacustrine hypothesis, such high sedimentation rates and turbidity would have significantly

659 curtailed any in situ primary productivity preventing the establishment of macrofaunal benthic

660 communities (Korsun \& Hald 1998; Gordillo \& Aitken 2001). The majority of microfossils would thus

661 be glacially/glaciofluvially reworked from earlier Irish and Celtic sea temperate and glacimarine

662 sequences. Under glacimarine conditions, some microfossils could be expected to have been 
663 advected from more distal areas on the open shelf (cf. Murdmaa et al. 2006), however, given the

664 durability and resistance to damage of organic-walled microfossils (in particular dinocysts)

665 distinguishing between wholly reworked mixed temperate and glacimarine, and dominantly

666 reworked mixed temperate and glacimarine (but with a minor in situ glacimarine component)

667 assemblages is problematic. Salinities may also have been low due to significant meltwater flux into

668 the basin. Nonetheless, with a connection to the North Atlantic, a tidal influence within the

669 embayment should be expected, though high bed shear stresses at this time would have most likely

670 prevented the deposition of glacimarine fines (Uehara et al. 2006; Scourse et al. 2009). Subsequent

671 sea-level increase associated with enhanced stormwave and tidal current erosion would have

672 resulted in erosion and winnowing of Unit III and generation of the Unit II lag deposit in a similar

673 fashion to the glacilacustrine hypothesis.

674 To accommodate the apparent uniformity seen in the Unit III litho- and bio-stratigraphy,

675 such a glacimarine model must be characterised by the rapid break-up and retreat of the ISIS

676 northwards from the basin rather than a gradual and sequential ice retreat. Successional changes

677 with increasing ice-distal conditions (Thomsen \& Vorren 1986; Korsun \& Hald 1998; Jaeger \&

678 Nittrouer 1999; Gilbert et al. 2002) are not evidenced in the Unit III waterlain glacigenic sediments.

679 Indeed, the relative rapid retreat of the ice margin from the Isles of Scilly to Anglesey $(<3000$ years;

680 Scourse et al. 2009b; McCarroll et al. 2010) is also consistent with this hypothesis. A previously

681 proposed (Scourse et al. 1990) deglacial iceshelf during Unit III deposition is hard to justify on

682 glaciological and palaeotidal grounds. Early deglacial water depths would have been too shallow and

683 with too greater tidal amplitude (Uehara et al. 2006; Scourse et al. 2009) to support a floating ice

684 margin (Benn \& Evans 2010) until the mid to late Holocene (e.g. Heyworth \& Kidson 1982; Shennan

685 et al. 2006; Brooks et al. 2008; Massey et al. 2008). Furthermore, Unit III sediments are not

686 consistent with extensive undermelt and rapid coarse clastic deposition from a debris-rich mid-

687 latitude iceshelf (Powell 1984; Syvitski 1991, Ó Cofaigh \& Dowdeswell 2001; Post et al. 2007).

688 


\subsection{Critique of Glacimarine and Glacilacustrine Hypotheses}

690 Both proposed hypotheses broadly accommodate the available data, making a determination

691 between either model problematic. Both predict rapid ice-distal laminated to massive fine grained

692 subaqueous sedimentation with a minor ice rafted coarse component, deposited under low energy

693 conditions. Both also require rapid deglaciation of the Celtic Sea to explain the lack of lateral or

694 vertical facies variation evident in the glacial waterlain sediments. Broadly analogous conditions

695 (though under greater water depths) persisted in the deglacial Barents Sea (Murdmaa et al. 2006),

696 and such a rapid deglaciation in a marine or lacustrine setting has been previously inferred for the

697 Celtic and southern Irish Sea (Scourse et al. 2009; McCarroll et al. 2010). This apparent rapid ice

698 retreat may indeed favour the glacimarine hypothesis whereby rising glacio-eustatic sea-levels

699 induce the destabilization and break-up of the ISIS during deglaciation, a forcing mechanism not

700 accommodated by a glacilacustrine model. Nonetheless, the presupposition of a deglacial tidal

701 connection to the North Atlantic across the Celtic Sea shelf is hard to reconcile with the fine-grained

702 nature of the Unit III sediments during a period when enhanced tidal bed shear vectors are

703 anticipated (Uehara et al. 2006; Neill et al. 2009; Scourse et al. 2009), whilst an iceshelf can be ruled

704 out on glaciological and palaeotidal grounds.

705 Biostratigraphically, both models predict the deposition of significant quantities of

706 palynomorphs, reworked from pre-existing marine and glacimarine sediments overridden by the

707 advancing ISIS, with minimal in situ production under high turbidity and low salinity. In both

708 scenarios, larger, calcareous, or more delicate materials are considered less likely to be preserved.

709 Glacigenic sediments, including glacilacustrine sequences, containing reworked marine micro- and

710 macro-fossils are common along the Celtic and Irish sea margins. Tills on the Llŷn Peninsula contain

711 reworked foraminifera derived Pleistocene temperate and glacimarine sequences overridden by the

712 ISIS (Austin \& McCarroll 1992) whilst similar foram-containing deposits along the eastern Irish coast

713 are also now considered subglacial till (McCarroll 2001) rather than glacimarine (Haynes et al. 1995).

714 At Killiney, Ireland, marine mollusc in presumed ice-proximal glacimarine diamictons (sensu Eyles \& 
715 McCabe 1989), are now considered reworked within terrestrial tills (Rijsdijk et al. 2010).

716 Glacilacustrine sequences on the Isle of Man (Thomas et al. 2004) show either barren or disparate

717 reworked foraminiferal assemblages, as do ice-marginal lacustrine sequences from Glacial Llyn Teifi

718 in SW Wales (Riding 1997; Fletcher \& Siddle 1998; Hambrey et al. 2001; Etienne et al. 2006). There is

719 thus clear evidence for glacial transport and lacustrine redeposition of reworked marine biota

720 associated with the glaciation of the Irish and Celtic seas. In the present study, this is supported by

721 the occurrence of a sparse reworked dinocyst and NPP assemblage within the basal Melville Till

722 diamicton (Unit IIIb) in CS-3 which strongly resemble those from Unit III (Melville Laminated Clay)

723 waterlain laminated muds. An ice-proximal glaciaqueous, as opposed to subglacial lodgement, origin

724 of the diamicton cannot be dismissed given the liquidity index of the samples (Lambert \& Khwaja

725 1978) at the base of core CS-3 where overconsolidation during core penetration is likely. The

726 apparent absence of any macro or micro marine indicators, aside from highly preservable

727 palynomorphs with a strong potential for reworking, and the presence of extremely rare freshwater

728 diatoms further argues in favour of a lacustrine system. Additionally, even under conditions of very

729 rapid marine deglaciation, lateral environmental gradients influencing benthic and planktonic

730 community structure, and thus preserved macro- and microfossil assemblages, should be expected

731 (Korsun \& Hald 1998; Jaeger \& Nittrouer 1999). This is especially true of large areas such as the

732 central and northern Celtic Sea where, under rapid ice retreat, ice distal locations may have been up

733 to $200 \mathrm{~km}$ from the calving margin. Furthermore, with increasingly distal glacimarine conditions a

734 succession from early colonizers to an established boreo-arctic flora and fauna should be observed

735 vertically through Unit III samples (Thomsen \& Vorren 1986). Neither of these patterns is evident.

736 Nonetheless, given the potential for very low salinities, high sedimentation rates, and high

737 meltwater efflux, and thus minimal in situ production, the glacimarine hypothesis cannot be wholly

738 ruled out on biostratigraphic grounds.

739 Timing of deglaciation in the Irish and Celtic seas, and the sea-levels in which it occurred,

740 remain debatable. A deglacial marine limit of $30 \mathrm{~m}$ asl is described by Clark et al. (2004) and McCabe 
741 et al. (2005) from Kilkeel on the northeast Irish coast with deglacial ${ }^{14} \mathrm{C}$ dates between 21 and $19 \mathrm{ka}$

742 BP. This, however, is exceptionally early, and hard to reconcile with other data suggesting much later

743 deglaciation this far north (McCarroll et al. 2010). Furthermore, the Kilkeel chronology is based on

744 bulk foraminiferal $\mathrm{AMS}{ }^{14} \mathrm{C}$ dates in an environment where the admixture of resuspended reworked

745 pre-LGM material is highly likely (cf. Austin \& McCarroll 1992; Thomas et al. 2004; Pieńkowski et al.

746 submitted), as indicated by re-deposited molluscs in the same unit (Rijsdijk et al. 2010). McCabe et

747 al. (2005) suggest a later lowstand between 18 and $16.7 \mathrm{ka} \mathrm{BP}$ (but 13.4 cal ka BP and $30 \mathrm{~m}$ below

748 modern sea-level in Belfast Lough according to Kelley et al. 2006) attributable to marked isostatic

749 rebound, though again, the chronology must be regarded with caution. From North Wales into the

750 Celtic Sea, deglaciation takes place with sea-levels lower than present on both Irish and British

751 coastlines (e.g. Rijsdijk et al. 2010; Roberts et al. 2011). This is counter to earlier work suggesting

752 glacial and deglacial sea-levels higher than present along the Irish coast of the southern Irish Sea in

753 particular (e.g. Eyles \& McCabe 1989; McCabe \& Ó Cofaigh 1995; McCabe et al. 1998; McCabe 2008).

754 Well constrained dates from the central Irish Sea place deglaciation around $19 \mathrm{ka}$ BP with dates of

755 18.1-19.2 cal ka BP for Holyhead Mountain (Anglesey) and $19{ }^{14} \mathrm{C}$ ka BP for Dundalk Bay (McCarroll et

756 al. 2010).

757 GIA models (Lambeck 1991, 1993, 1995, 1996; Lambeck \& Purcell 2001) suggest the

758 significant exposure of continental shelf in the Celtic Sea following deglaciation and the persistence

759 of an isolated CDB lacustrine system. Deglaciation northwards through the Irish Sea in contact with a

760 large standing water body is evidenced by swath bathymetry from north of Anglesey (van

761 Landeghem et al. 2009). Given the modern bathymetry, even accounting for isostatic rebound and

762 Holocene erosion and deposition, such conditions might have extended southwards through St

763 Georges Channel into the CDB. Furthermore, deglacial dates of 20.9-22.1 cal ka BP (Scourse \& Furze

764 2001; McCarroll et al. 2010) from the northern margin of the Isles of Scilly (southern ISIS limit)

765 provide an approximate age on Celtic Sea deglaciation. Both hypotheses can be accommodated by

766 the available deglacial and sea-level data from the Irish and Celtic Sea basins. The age of $13.9 \mathrm{cal}$ ka 
767 BP from CD-8 for the onset of marked marine erosion and bioclastic lag generation is a minimum

768 value given the potential for time averaging and condensation in such lag sediments. Remnant (and

769 confluent) British and Irish ice remained over the North Channel between NE Ireland and SW

770 Scotland until after 16 cal ka BP (e.g. Shennan et al. 2006).

771 Geomorphically, the glacilacustrine hypothesis is harder to accommodate than the

772 glacimarine model. While the glacio-isostatic rebound models of Lambeck $(1995,1996$, in Uehara et

773 al. 2006), Lambeck \& Purcell (2001), and Peltier et al. (2002) predict an isolation basin in the CDB

774 during low postglacial sea-levels, consistent with a glacilacustrine interpretation of Unit III in this

775 area (cores CD-1 to -9), similar Unit III deposits on the open shelf south of the CDB sill are harder to

776 explain (cores CS-1 to -3). If glacilacustrine, an extensive area of subaerially exposed shelf

777 characterised by moraine-dammed and kettle lake basins peripheral to the main CDB system must

778 be invoked, extending southwards to at least the location of CS-3 (VE 49/-09/044) and the modern

$779120 \mathrm{~m}$ isobath. Despite the fact that there exists little stratigraphic or seismic evidence from the

780 Celtic Sea to support this, the latest Lambeck GIA model (in Uehara et al. 2006; Scourse et al. 2009)

781 does depict sufficiently extensive subaerial shelf exposure from $21 \mathrm{ka}$ BP until after $15 \mathrm{ka}$ BP lending

782 some credence to this hypothesis. Furthermore, the model predicts marine ingression and final

783 breaching of the CDB's southern sill shortly before $14 \mathrm{ka} B P$, consistent with the oldest marine dates

784 of 13.9 cal ka BP from the erosional lag of Unit II. This, too, is reconcilable with the deglacial records

785 farther north in the Irish Sea if problematic deglacial foraminiferal dates are discounted.

786

$787 \quad 5.3$ Implications

$788 \quad$ 5.3.1 Irish Biogeography

789 A lacustrine system (and thus a Celtic Sea landbridge) before 13.9-14 cal ka BP has direct

790 implications for Ireland's postglacial biogeography. Irish faunas from the late glacial and early

791 Holocene are impoverished compared to those from the same time period in Britain (Stuart 1977,

792 1995; Yalden 1982; Stuart \& van Wijngaarden-Bakker 1985; Woodman et al. 1997; Coard \& 
793 Chamberlin 1999). The impoverishment and arrival times of different species into Ireland has been

794 used to argue both for and against the existence of landbridges. Some authors (Stuart \& van

795 Wijngaarden-Bakker 1985; Dobson 1994; Stuart 1995; Lynch 1996; Stewart \& Lister 2001;

796 Mascheretti et al. 2003; Teacher et al. 2009) conclude that no terrestrial link existed since before the

797 last cold stage. A reduced pre-Midlandian/Devensian fauna either persisted in cryptic ice-free refugia

798 (unsupported by glaciological evidence), or was derived from terrestrial taxa crossing marine

799 channels between Britain and Ireland.

800 The potentially glacilacustrine sequences of the Celtic Sea, in combination with latest GIA

801 model of Lambeck (in Uehara et al. 2006) counter arguments of Irish insularity, suggesting an

802 ephemeral isthmus prior to the Younger Dryas ( 13000 BP). The distribution of taxa in southern

803 Ireland and mainland Europe favours an early southern Celtic Sea immigration corridor (Preece et al.

804 1986; Seyd 1992; Gleed-Owen 1997; Woodman et al. 1997) lending credence to the glacilacustrine

805 hypothesis.

806

$807 \quad$ 5.3.2 Celtic Sea Linear Sand Ridges (LSRs)

808 If the glacilacustrine model proposed here is accepted, it implies the existence of not only a CDB lake

809 system, but numerous shallow peripheral kettle and moraine-dammed lakes across the recently

810 deglaciated subaerial shelf. The occurrence of glaciaqueous units interpretable as glacilacustrine in

811 BGS vibrocores VE 49/-09/044 (Scourse et al. 1990, 1991; core CS-3 this study) and VE 50/-07/141

812 (core CS-1 this study) south of the CDB on the open shelf is consistent with this model. Furthermore,

813 a glacilacustrine interpretation of Unit III muds in core CS-3 (VE 49/-09/044) has implications for

814 understanding the development of the Celtic Sea LSR system. This vibrocore was recovered from the

815 flanks of one of the most northerly LSRs and its interpretation as a lodgement till and glacimarine

816 sequence draping an earlier LSR deposit is critical for the hypothesis that LSR development predated

817 the MIS2 advance of the ISIS (Bouysse et al. 1976; Pantin \& Evans 1984; Belderson et al. 1986;

818 Scourse et al. 1990, 1991; Reynaud et al. 1995, 1999). However, recent modelling and seismic data 
819 suggest that though some LSRs may indeed be cored by older deltaic and estuarine sediments, the

820 main period of LSR development was between 20 and 12 ka BP under rising eustatic sea-levels and

821 sediment cannibalization from the extensive midshelf depocentres of the Fleuve Manche estuary

822 and the ISIS fan (Lericolais et al. 2003; Reynaud et al. 2003; Scourse et al. 2009).

823 The laminated sediments of Unit III in core CS-3 (VE 49/-09/044; Melville Laminated Clay of

824 Scourse et al. 1990, 1991) are clearly different to similar deposits to the south, with an absence of

825 marine macrofossils, and microfossil assemblages suggestive of glacilacustrine redeposition. If this

826 core thus records glacilacustrine rather than glacimarine conditions, and if those glacigenic

827 sediments (Units III and IIIb; Melville Laminated Clay and Melville Till) outcrop from the side of the

828 LSR rather than drape it, then a subaerial interval on the central Celtic Sea shelf followed by

829 inundation and LSR development as outlined by Scourse et al. (2009) is plausible and consistent with

830 the glacilacustrine model. However, until more detailed high resolution seismic data and long core

831 records are available from the area this aspect of the hypothesis will remain untested.

832

833 5.3.3 Deglacial Styles

834 The maximum extent of the LGM BIIS in the Celtic Sea is yet to be established (Sejrup et al. 2005)

835 though it is thought to have terminated in a tidewater margin south of $49^{\circ} 30^{\prime} \mathrm{N}$ (Scourse et al. 1990,

836 1991; Scourse \& Furze 2001). While surging behaviour across a deformable bed has been invoked for

837 the development of the ISIS lobe in the Celtic Sea (Scourse \& Furze 2001; Ó Cofaigh \& Evans 2001a,

838 b, 2007; Roberts et al. 2007; McCarroll et al. 2010), a glacilacustrine hypothesis would imply the

839 retreat of a terrestrial margin northwards across the Celtic Sea shelf before the establishment of a

840 lacustrine calving margin in the CDB and a connected southern Irish Sea lake system. However, once

841 established in the topographic depression of the CDB and St George's Channel, calving of the ISIS

842 may have been particularly rapid as deeper water conditions (a function of bathymetry and

843 increased isostatic depression) would be encountered northward. Rapid deglaciation is indicated by

844 a mere 3000 year difference between Isles of Scilly (20.9-22.1 cal ka BP) and Holyhead Mountain, 
845 Anglesey (18.1-19.2 cal ka BP; McCarroll et al. 2010). Van Landeghem et al. (2009) presents detailed

846 swath bathymetry evidence of subaqueous deglacial bedforms from west of Anglesey consistent

847 with ice retreat in both lacustrine and marine settings.

848

\section{$849 \quad$ 5.3.4 Unresolved Issues}

850 Both the proposed glacimarine and glacilacustrine hypotheses for the deglacial and post glacial Celtic

851 Sea remain speculative. In particular, the high preservation potential of organic-walled microfossils

852 (primarily dinoflagellate cysts and foram linings) makes the determination of low productivity

853 glacimarine and glacilacustrine systems subject to the resuspension and redeposition of older glacial

854 reworked marine sediments problematic. We are unaware of any systematic assemblage structure

855 or taphonomic studies of organic-walled microfossils from marine-derived tills and glacilacustrine

856 sediments around the margins of the Celtic and Irish seas or analogous environments. The degree to

857 which such microfossils can be reworked with little or no morphological modification thus remains

858 undetermined.

859 If the glacimarine as opposed to the glacilacustrine model is accepted, the absence of in situ

860 micro- and macro-palaeontological materials from the Unit III mud deposits within the BIIS limits as

861 opposed to the rich in situ glacimarine faunas in similar deposits beyond needs to be explained,

862 especially given the inferred time-transgressive nature of such deposits during ice retreat.

863 Furthermore, the degree to which Unit III has been eroded and winnowed, potentially resulting in

864 the loss of indicative (and conceivably fossiliferous) ice-distal glaciaqueous horizons remains

865 unquantified. There also remains a mismatch between palaeotidal models (Uehara et al. 2006)

866 suggesting elevated peak bed shear stresses during the immediate deglacial period and the fine-

867 grained nature of those deglacial sediments (Unit III this study, Melville Laminated Clays of Scourse

868 et al. 1990, 1991).

869 Clearly, there is a pressing need to further refine and test the competing hypotheses of

870 Celtic Sea shelf deglacial and postglacial evolution. In particular, if the Unit II muds are indeed 
871 lacustrine within the central and northern Celtic Sea regions, how extensive was the implied

872 subaerially exposed shelf, and when did the final eustatically-driven separation between Britain and

873 Ireland occur? Building on this study, and the earlier work of Scourse et al. (1990, 1991), a detailed

874 multiproxy micro- and macro-palaeontological analysis of all units of the Melville Formation

875 (including the laminated clays and till) from the "proven" glacimarine units on the shelf edge

876 through to the Unit III sequences in the northern CDB is required to examine if lateral biofacies

877 variations are or are not apparent. Additionally, detailed microstratigraphic analysis of the laminated

878 sequences across the Celtic Sea shelf, as well as geochemical or biogeochemical analysis of those

879 glaciaqueous deposits may further advance the exploration of the lacustrine and marine deglacial

880 hypotheses.

881 Until then, this study represents the first systematic, critical analysis of Celtic Sea deglacial to 882 postglacial environments highlighting the complexities inherent where a major icestream overriding 883 previous marine sediments terminates in, and retreats from, a mid-shelf setting. Given the far884 reaching implications for the Quaternary of the British Isles associated with either hypothesis, this 885 work raises crucial questions regarding the style and timing of deglaciation, and sea-levels in which 886 this occurred.

\section{6. Conclusions}

889 The character of late Pleistocene deglaciation in the central and northern Celtic Sea (including the

890 Celtic Deep Basin) remains unresolved. Based on the absence of (glaci)marine macrofossils, diatoms,

891 and foraminifera, and the presence of redeposited and environmentally incompatible dinocysts in

892 regionally extensive deglacial waterlain deposits, two competing hypotheses are proposed: 1) a

893 glacimarine model with the rapid retreat of an Irish Sea Ice Stream calving margin in contact with the

894 sea northwards across the shelf into St George's Channel; 2) a glacilacustrine model with initially

895 subaerial ice retreat exposing a system of ephemeral lacustrine basins across the shelf and the

896 northward calving of the ice margin in an extensive Celtic Deep lake basin, potentially extending 
897 northwards into the southern and central Irish Sea. In the latter model, all encountered

898 palynomorphs are considered redeposited from glacial (and or glacifluvially) reworked older marine 899 sequences in the Celtic and Irish seas.

900 Based on the absence of any dated (molluscan) macrofossils older than 13.5-14.2 cal ka BP

901 from extensive overlying erosional lag deposits and the apparent agreement with the GIA

902 simulations of Lambeck (in Uehara et al. 2006 and Scourse et al. 2009), the glacilacustrine model is

903 favoured. However, until sufficient data is available to test either hypothesis further, such an

904 interpretation must remain speculative. Given the important implications that this has for

905 understanding the late Quaternary environmental evolution of the NW European shelf, there

906 remains a need for further research to establish the nature and timing of Celtic Sea deglaciation.

907

908 Acknowledgments

909 MFAF gratefully acknowledges the receipt of a NERC PhD research studentship grant

910 (GT04/97/289/ES) and two NSERC-funded radiocarbon allocations (746/0898; 814/0999) in support

911 of this research. Also gratefully acknowledged is the award of an RSACAF grant and a Professional

912 Development Conference Attendance grant from Grant MacEwan University to MFAF. Staff at the

913 NERC Radiocarbon Facility in East Kilbride, Scotland, in particular Charlotte Bryant, Brian Miller, and

914 Margaret Currie must be thanked for their valued discussions regarding radiocarbon dating issues.

915 Thanks must also be extended to the British Geological Survey for making core materials central to

916 this study available, in particular Helen Glaves, Graham Tulloch, and the late Robin Wingfield.

917 Douglas Peacock, Vera Pospelova, Kenneth Mertens, John England, and David Evans are also highly

918 deserving of thanks for fruitful discussions essential to the development of this paper. AJP wishes to

919 thank Charlie Schweger and Harvey Friebe at the University of Alberta for the generous use of their

920 Environmental Archaeology Laboratory in the preparation and processing of dinoflagellate cysts and

921 other non-pollen playnomorphs. This is a contribution to the Climate Change Consortium of Wales

922 (C3W). 
923

924 References

925 Andrews, J.T., Jennings, A E., MacLean, B., Mudie, P.J., Praeg, D. \& Vilks, G. 1991: The surficial

926 geology of the Canadian eastern Arctic and Polar continental shelves. Continental Shelf

$927 \quad$ Research 11, 791-819.

928 Appeltans, W., Bouchet, P., Boxshall, G.A., Fauchald, K., Gordon, D.P., Hoeksema, B.W., Poore,

929 G.C.B., van Soest, R.W.M., Stöhr, S., Walter, T.C. \& Costello, M.J. (eds) 2011: World Register of

$930 \quad$ Marine Species. Accessed at http://www.marinespecies.org on 2011-12-28.

931 Austin, W.E.N. \& McCarroll, D. 1992: Foraminifera from the Irish Sea glacigenic deposits at

932 Aberdaron, western Lleyn, North Wales: palaeoenvironmental implications. Journal of

$933 \quad$ Quaternary Science 7, 311-317.

934 Austin, W.E.N. \& Scourse, J.D. 1997: Evolution of seasonal stratification in the Celtic Sea during the

935 Holocene. Journal of the Geological Society of London 154, 249-256.

936 Bathman, U.V., Noji, T.T. \& von Budengen, B. 1991: Sedimentation of pteropods in the Norwegian

937 Sea in autumn. Deep-Sea Research 38, 1341-1360.

938 Battarbee, R.W., Jones, V.J., Flower, R.J., Cameron, N.G., Bennion, H., Carvalho, L. \& Juggens, S.

939 2001: Diatoms. In Smol, J.P., Birks, H.J.B. \& Last, W.M. (eds.): Tracking Environmental Change

940 Using Lake Sediments, Volume 3, Terrestrial, Algal, and Siliceous Indicators. Kluwer Academic

941 Publishers, Dordrecht, 155-202.

942 Belderson, R.H., Pingree, R.D. \& Griffiths, D. 1986: Low sea-level tidal origin of Celtic Sea sand banks:

943 Evidence from numerical modelling of M2 tidal streams. Marine Geology 73, 99-108.

944 Benn, D.I. \& Evans, D.J.A. 2010: Glaciers and Glaciation. Hodder Education Publishers, London.

945 Bouysse, P., Horn, R., Lapierre, F. \& Le Lann, F. 1976: Étude des Grands Bancs de Sable du Sud-est de

946 la Mer Celtique. Marine Geology 20, 251-275. 
947 Brooks, A.J., Bradley, S.L., Edwards, R.J., Milne, G.A., Horton, B. \& Shennan, I. 2008: Postglacial

948 relative sea-level observations from Ireland and their role in glacial rebound modelling. Journal

949 of Quaternary Science 23, 175-192.

950 Chiverrell R.C. \& Thomas G.S.P. 2010: Extent and timing of the Last Glacial Maximum (LGM) in Britain

951 and Ireland: a review. Journal of Quaternary Science 25, 535-549.

952 Clark, P.U., McCabe, A.M., Mix, A.C. \& Weaver, A.J. 2004: Rapid Rise of Sea Level 19,000 Years Ago

$953 \quad$ and Its Global Implications. Science 304, 1141-1144

954 Coard, R. \& Chamberlin, A.T. 1999: The nature and timing of faunal change in the British Isles across

955 the Pleistocene/Holocene transition. The Holocene 9, 372-376

956 Cowan, E.A. \& Powell, R.D. 1990: Suspended sediment transport and deposition of cyclically

957 interlaminated sediment in a temperate glacial fjord, Alaska, USA. In Dowdeswell, J.A. \&

958 Scourse, J. D. (eds): Glacimarine Environments: processes and sediments. Glacimarine

959 Environments: Processes and Sediments, 75-89. Geological Society of London. Special

$960 \quad$ Publication 53.

961 Cowan, E.A., Cai, J., Powell, R.D., Seramur, K.C., Spurgeon, V.L., 1998. Modern tidal rhythmites

962 deposited in a deepwater estuary, southeast Alaska. Geomarine Letters 18, 40-48.

963 Cowan, E., Seramur, K.C., Cai, J., Powell, R.D., 1999. Cyclic sedimentation produced by fluctuations in

964 meltwater discharge, tides and marine productivity in an Alaskan fjord. Sedimentology 46, 1109-

9651126.

966 Coxon, P. \& Waldren, S. 1995: The floristic record of Ireland's Pleistocene temperate stages. In

967 Preece, R.C. (ed.) Island Britain: a Quaternary perspective. Geological Society Special Publication

$96896,243-267$.

969 Desloges, J.R., Gilbert, R., Nielsen, N., Christiansen, C., Rasch, M., Whlenschlager, R., 2002: Holocene

970 sedimentary environments in fiords of Disko Bugt, West Greenland. Quaternary Science Reviews

$971 \quad 21,947-963$. 
972 de Vernal, A., Bilodeau, G., Hillaire-Marce, C. \& Kassou N. 1992: Quantitative assessment of

973 carbonate dissolution in marine sediments from foraminifer linings vs. shell ratios: Davis Strait,

974 northwest North Atlantic. Geology 20, $527-530$.

975 Devoy, R.J. 1983: Late Quaternary shorelines in Ireland: an assessment for their implications for

976 isostatic land movement and relative sea-level changes. In Smith, D.E. \& Dawson, R.G. (eds.):

977 Shorelines and Isostasy. Institute of British Geographers, Special Publication 16, 227-254.

978 Devoy, R.J. 1985: The problem of a Late Quaternary landbridge between Britain and Ireland.

979 Quaternary Science Reviews 4, 43-58.

980 Devoy, R.J. 1986: Possible Land-bridges Between Ireland and Britain: a Geological Appraisal. In

981 Sleeman, D.P., Devoy, R.J. \& Woodman, P.C. (eds.): Proceedings of the Postglacial Colonization

982 Conference. Irish Biogeographical Society, Occasional Publication 1, 15-26.

983 Devoy, R.J. 1995: Deglaciation, Earth crustal behaviour and sea-level changes in the determination of

984 insularity: a perspective from Ireland. In Preece, R.C. (ed.): Island Britain: a Quaternary

985 perspective. Geological Society of London, Special Publication 96, 181-208.

986 Dobson, M. 1994: Patterns of distribution in Japanese land mammals. Mammal Review 24, 91-111.

987 Dodge, J.D. \& Harland, R. 1991: The Distribution of Planktonic Dinoflagellates and Their Cysts in the

988 Eastern and Northeastern Atlantic Ocean. New Phytologist 118, 593-603.

989 England, J., Dyke, A.S., Coulthard, R.D., McNeely, R., Aitken, A., 2012: The exaggerated radiocarbon

990 age of deposit-feeding molluscs in calcareous environments. Boreas 10,

$991 \quad$ 1111/j.15023885.2012.00256.x.

992 Etienne, J.L., Jansson, K.N., Glasser, N.F., Hambrey, M.J., Davies, J.R., Waters, R.A., Maltman, A.J. \&

993 Wilby, P.R. 2006: Palaeoenvironmental interpretation of an ice-contact glacial lake succession:

994 an example from the late Devensian of southwest Wales, UK. Quaternary Science Reviews 25,

$995 \quad 739-762$.

996 Evans, C.D.R. 1990: The geology of the western English Channel and its western approaches. U.K.

997 Offshore Regional Report. British Geological Survey. HMSO, London. 
998 Evans, D.J.A. \& Ó Cofaigh, C. 2003: Depositional evidence for marginal oscillations of the Irish Sea ice 999 stream in southeast Ireland during the last glaciation. Boreas 32, 76-101.

1000 Eyles, N. \& McCabe, A.M. 1989:The Late Devensian (<22,000 BP) Irish Sea Basin: the sedimentary 1001 record of a collapsed ice sheet margin. Quaternary Science Reviews 8, 307-351.

1002 Eyles, N. \& McCabe, A.M. 1991: Glaciomarine deposits of the Irish Sea Basin: the role of glacio1003 isostatic disequilibrium. In Ehlers, J., Gibbard, P.L. \& Rose, J. (eds.): Glacial Deposits in Great 1004 Britain and Ireland. A.A. Balkema, Rotterdam, 311-331.

1005 Eyles, N., Eyles, C. H. \& Maill, A. D. 1983: Lithofacies types and vertical profile models; an alternative 1006 approach to the description and environmental interpretation of glacial diamict and diamictite sequences. Sedimentology 30, 393-410.

1008 Fletcher, C.J.N. \& Siddle, H.J. 1998: Development of glacial Llyn Teifi, west Wales: evidence for lake1009 level fluctuations at the margins of the Irish Sea ice sheet. Journal of the Geological Society of $1010 \quad$ London 155, 389-399.

1011 Freeman-Lynde, R.P., Hutchinson, D.R., Folger, D.W., Wiley, B.H. \& Hewett, M.J. 1980: The Origin

1012 and Distribution of Subbottom Sediments in Southern Lake Champlain. Quaternary Research 14, $1013 \quad 224-239$.

1014 Fürsich, F.T. \& Aberhan, M. 1990: Significance of time-averaging for palaeocommunity analysis. $1015 \quad$ Lethaia 23, 143-152.

1016 Gallager, S.M., Davis, C.S., Epstein, A.W., Solow, A. \& Beardsley, R.C. 1996: High resolution 1017 observations of plankton spatial distributions correlated with hydrography in the Great 1018 Southern Channel, Georges Bank. Deep Sea Research 43, 1627-1663.

1019 Gilbert, R., Nielsen, N., Desloges, J.R., Rasch, M., 1998: Contrasting glacimarine sedimentary 1020 environments of two arctic fiords on Disko, West Greenland. Marine Geology 147, 63-83.

1021 Gilbert, R., Nielsen, N., Möller, H., Desloges, J.R. \& Rasch, M. 2002: Glacimarine sedimentation in 1022 Kangerdluk (Disko Fjord), West Greenland, in response to a surging glacier. Marine Geology 191, $1023 \quad 1-18$ 
1024 Gleed-Owen, C. 1997: The Devensian Late-glacial arrival of natterjack toad, Bufo calamita, in Britain

1025 and its implications for colonisation routes and land-bridges. Quaternary Newsletter 81, 18-24.

1026 Gordillo, S., \& Aitken, A.E. 2001: Postglacial succession of Late Quaternary macrofaunal assemblages 1027 from the central Canadian Arctic Archipelago. Boreas 30, 61-72.

1028 Gowen, R.J., Raine, R., Dickey-Collas, M. \& White, M. 1998: Plankton distributions in relation to 1029 physical oceanographic features on the southern Malin Shelf, August 1996. ICES Journal of $1030 \quad$ Marine Science 55, 1095-1111.

1031 Graham, A. 1988: Molluscs: Prosobranch and Pyramidellid Gastropods. Linnean Society Synopses of 1032 the British Fauna (ns), 2 (2nd ed.), 1-662.

1033 Hambrey, M.J., Davies, J.R., Glasser, N.F., Waters, R.A., Dowdeswell, J.A., Wilby, P.R., Wilson, D. \&

1034 Etienne, J.L. 2001: Devensian glacigenic sedimentation and landscape evolution in the Cardigan 1035 area of southwest Wales. Journal of Quaternary Science 16, 455-482.

1036 Harland, R. 1983: Distribution maps of recent Dinoflagellate cysts in bottom sediments from the 1037 North Atlantic Ocean and adjacent seas. Paleontology 26, 321-387.

1038 Harland, R. 1994: Dinoflagellate cysts from the glacial/postglacial transition in the northeast Atlantic 1039 Ocean. Palaeontology 37, 263-283.

1040 Haynes, J.R., McCabe, A.M. \& Eyles, N. 1995: Microfaunas from Late Devensian Glaciomarine 1041 Deposits in the Irish Sea Basin. Irish Journal of Earth Sciences 14, 81-103.

1042 Hayward, P.J. \& Ryland, J.S. (eds.) 1998: Handbook of the Marine Fauna of North-West Europe.

$1043 \quad$ Oxford University Press, Oxford.

1044 Head, M.J., Seidenkrantz, M.-S., Janczyk-Kopikowa, Z., Marks, L. \& Gibbard, P.L. 2005: Last

1045 Interglacial (Eemian) hydrographic conditions in the southeastern Baltic Sea, NE Europe, based

1046 on dinoflagellate cysts. Quaternary International 130, 3-30.

1047 Heyworth, A. \& Kidson, C. 1982: Sea-level changes in southwest England and Wales. Proceedings of 1048 the Geologists' Association 93, 91-111. 
1049 Hiemstra, J.F., Evans, D.J.A., Scourse, J.D., McCarroll, D., Furze, M.F.A. \& Rhodes, E. 2006: New

1050 evidence for a grounded Irish Sea glaciation of the Isles of Scilly, UK. Quaternary Science

$1051 \quad$ Reviews 25, 299-309.

1052 Jaeger, J.M., Nittrouer, C.A., 1999: Marine record of surge-induced outburst floods from the Bering $1053 \quad$ Glacier, Alaska. Geology 27, 847-850.

1054 Jeffrey, D. 1990: Comment by D. Jeffery. In "Glacial incisions indicating Middle and Upper

$1055 \quad$ Pleistocene ice limits off Britain" - two comments and a reply. Terra Nova 2, 383-385.

1056 Kelley, J.T., Cooper, J.A.G., Jackson, D.W.T., Belknap, D.F. \& Quinn, R.J. 2006: Sea-level change and inner shelf stratigraphy off Northern Ireland. Marine Geology 232, 1-15.

1058

Kerr, D.E. 1987: Depositional environments during a glaciolacustrine to marine transition in the Richardson and Rae River basin, N.W.T. Canadian Journal of Earth Sciences 24, 2130-2140.

Kidwell, S.M. 1998: Time-averaging in the marine fossil record: overview of strategies and

1061 uncertainties. GEOBIOS 30, 977-995.

1062

Kidwell, S.M. 2002: Time-averaged molluscan death assemblages: Palimpsests of richness, snapshots of abundance. Geology 30; 803-806.

Korsun, S. \& Hald, M. 1998: Modern Benthic Foraminifera off Novaya Zemlya Tidewater Glaciers, 1065 Russian Arctic. Arctic and Alpine Research 30, 61-77.

1066 Kowalewski, M. Goodfriend, G.A. \& Flessa, K.W. 1998: High-resolution estimates of temporal mixing 1067 within shell beds: the evils and virtues of time-averaging. Paleobiology 24, 387-304.

1068 Krammer, K. \& Lange-Bertalot, H. 1991: Bacillariophyceae. 3. Teil: Centrales, Fragilariaceae,

1069 Eunotiaceae. In Ettl, H., Gerlof, J., Heynig, H. \& Mollenhauer, D. (eds.): Süßwasserflora von

1070 Mitteleuropa, Band 2/3. Gustav Fischer Verlag, Stuttgart, Germany.

1071 Krammer, K. \& Lange-Bertalot, H. 1997: Bacillariophyceae. 1. Teil: Naviculaceae. In Ettl, H., Gerlof, J., 1072 Heynig, H. \& Mollenhauer, D. (eds.): Süßwasserflora von Mitteleuropa, Band 2/1. Gustav Fischer $1073 \quad$ Verlag, Stuttgart, Germany.

1074 Lambeck, K. 1991: Glacial rebound and sea-level change in the British Isles. Terra Nova 3, $379-389$. 
1075 Lambeck, K. 1993: Glacial Rebound of the British Isles. II; A high resolution, high-precision model.

1076 Geophysics Journal International 115, 960-990.

1077 Lambeck, K. 1995: Late Devensian and Holocene shorelines of the British Isles and North Sea from

1078 models of glacio-hydro-isostatic rebound. Journal of the Geological Society of London 152, 437-

1079448.

1080 Lambeck, K. 1996: Glaciation and sea-level change for Ireland and the Irish Sea since Late

1081 Devensian/Midlandian time. Journal of the Geological Society of London 153, 853-872.

1082 Lambeck, K. \& Purcell, A.P. 2001: Sea levels in the Irish Sea since the Last Glacial Maximum: results

1083 from isostatic modelling. Journal of Quaternary Science 16, 497-506.

1084 Lambert, J.T. \& Khawaja, Z.M. 1978: Geotechnical analysis of till like material from the SW

1085 Approaches. Institute of Geological Sciences Engineering Geology Unit Internal Report No.

$1086 \quad 78 / 23,1-6$

1087 Lericolais, G., Auffret, J.-P. \& Bourillet, J.-F. 2003: The Quaternary Channel River: seismic stratigraphy

1088 of its palaeo-valleys and deeps. Journal of Quaternary Science 18, 245-260.

1089 Lynch, J.M. 1996: Postglacial colonization of Ireland by mustelids, with particular reference to the 1090 badger (Meles meles L.). Journal of Biogeography 23, 179-185.

1091 MacLean, B., Sonnichsen, G., Vilks, G., Powell, C., Moran, K., Jennings, A., Hodgson, D. \& Deonarine,

1092 B. 1989: Marine geological and geotechnical investigations in Wellington, Byam Martin, Austin, 1093 and adjacent channels, Canadian Arctic Archipelago. Geological Survey of Canada, Paper 89-11, $1094 \quad 1-69$.

1095 Marret, F. \& Scourse, J.D. 2002: Control of modern dinoflagellate cyst distribution in the Irish and 1096 Celtic seas by seasonal stratification dynamics. Marine Micropaleontology 47, 101-116.

1097 Marret, F. \& Zonneveld, K.A.F. 2003: Atlas of modern organic-walled dinoflagellate cyst distribution. 1098 Review of Paleobotany and Palynology 125, 1-200.

1099 Marret, F., Scourse, J.D., Austin, W.E.N. 2004: Holocene shelf-sea seasonal stratification dynamics: a 1100 dinoflagellate cyst record from the Celtic Sea, NW European shelf. The Holocene 14, 689-696. 
1101 Marsset, T., Tessier, B., Reynaud, J.-Y., De Batist, M. \& Plagnol, C. 1999: The Celtic Sea banks: an

1102 example of sand body analysis from very high-resolution seismic data. Marine Geology 158, 89-

1103109.

1104 Mascheretti, S., Rogatcheva, M.B., Gündüz, I., Fredga, K. \& Searle, J.B. 2003: How did the pygmy

1105 shrews colonize Ireland? Clues from a phylogenetic analysis of mitochondrial cytochrome $b$

1106 sequences. Proceedings of the Royal Society of London B 270, 1593-1599.

1107 Massey, A.C., Gehrels, W.R., Charman, D.J., Milne, G.A., Peltier, W.R., Lambeck, K. \& Selby, K.A. 2008:

1108 Relative sea-level change and postglacial isostatic adjustment along the coast of south Devon,

$1109 \quad$ United Kingdom. Journal of Quaternary Science 23, 415-433.

1110 Matthiessen, J., de Vernal, A., Head, M., Okolodkov, Y., Zonneveld, K. \& Harland, R. 2005: Modern

1111 organic-walled dinoflagellate cysts in Arctic marine environments and their

1112 (paleo)environmental significance. Paläontologische Zeitschrift 79, 3-51.

1113 McCabe, A.M. 2008: Comment: Postglacial relative sea-level observations from Ireland and their role

1114 in glacial rebound modelling. Journal of Quaternary Science 23, 817-820.

1115 McCabe, A.M. \& Ó Cofaigh, C. 1995: Late Pleistocene morainal bank facies at Greystones, eastern

1116 Ireland: an example of sedimentation during ice marginal re-equilibration in an isostatically

1117 depressed basin. Sedimentology 42, 647-663.

1118 McCabe, A.M., Knight, J. \& McCarron, S. 1998: Evidence for Heinrich event 1 in the British Isles.

1119 Journal of Quaternary Science 13, 549-568.

1120 McCabe, A.M., Clark, P.U. \& Clark, J. 2005: AMS ${ }^{14}$ C of deglacial events in the Irish Sea Basin and

1121 other sectors of the British-Irish ice sheet. Quaternary Science Reviews 24, 1673-1690.

1122 McCarroll, D. 2001: Deglaciation of the Irish Sea Basin: a critique of the glaciomarine hypothesis.

1123 Journal of Quaternary Science 16, 393-404.

1124 McCarroll, D., Stone, J.O., Ballantyne, C.K., Scourse, J.D., Fifield, L.K., Evans, D.J.A. \& Hiemstra, J.F.

1125 2010: Exposure-age constraints on the extent, timing and rate of retreat of the last Irish Sea ice 1126 stream. Quaternary Science Reviews 29, 1844-1852. 
1127 McCarthy, F.M.G., Gostlin, K.E., Mudie, P.J. \& Hopkins, J.A. 2003: Terrestrial and marine

1128 palynomorphs as sea-level proxies: an example from Quaternary sediments on the New Jersey

1129 margin, U.S.A. In Olson, H.C. \& Leckie, R.M. (eds.): Micropaleontologic Proxies for Sea-Level

$1130 \quad$ Change and Stratigraphic Discontinuities. SEPM (Society for Sedimentary Geology) Special

$1131 \quad$ Publication No. 75, 119-129.

1132 Mudie, P.J. 1992: Circum-Arctic Quaternary and Neogene marine palynofloras: paleoecology and

1133 statistical analysis. In Head, M.J. \& Wrenn, J.H. (eds.): Neogene and Quaternary Dinoflagellate

1134 Cysts and Acritarchs. American Association of Stratigraphic Palynologists: Foundation: Dallas,

1135 TX; 347-390.

1136 Mudie, P.J., Rochon, A., Prins, M. A., Soenarjo, D., Troelstra, S.R., Levac, E., Scott, D. B., Roncaglia, L.

1137 \& Kuijpers, A. 2006: Late Pleistocene-Holocene marine geology of Nares Strait region:

1138 palaeoceanography from foraminifera and \dinoflagellate cysts, sedimentology and stable

1139 isotopes. Polarforschung 74, 169-183.

1140 Murdmaa, I., Ivanova, E., Duplessy, J.-C., Levitan, M., Khusid, T., Bourtman, M., Alekhina, G.,

1141 Alekseeva, T., Belousov, M. \& Serova, V. 2006: Facies system of the Eastern Barents Sea since

1142 the last glaciation to present. Marine Geology 230, 275-303.

1143 Neill, S.P., Scourse, J.D., Bigg, G.R. \& Uehara, K. 2009: Changes in wave climate over the northwest

1144 European shelf seas during the last 12,000 years. Journal of Geophysical Research 114, C06015, 1145 doi:10.1029/2009JC005288.

1146 Ó Cofaigh, C. \& Dowdeswell , J.A. 2001: Laminated sediments in glacimarine environments:

1147 diagnostic criteria for their interpretation. Quaternary Science Reviews 20, 1411-1436.

1148 Ó Cofaigh, C. \& Evans, D.J.A. 2001a: Sedimentary evidence for deforming bed conditions associated

1149 with a grounded Irish Sea glacier, southern Ireland. Journal of Quaternary Science 16, 435-454.

1150 Ó Cofaigh, C. \& Evans, D.J.A. 2001b: Deforming bed conditions associated with a major ice stream of 1151 the last British ice sheet. Geology 29, 795-798. 
1152 Ó Cofaigh, C. \& Evans, D.J.A. 2007: Radiocarbon constraints on the age of the maximum advance of 1153 the British-Irish Ice Sheet in the Celtic Sea. Quaternary Science Reviews 26, 1197-1203.

1154 Pantin, H.M. 1977: Quaternary sediments from the northern Irish Sea. In Kidson, C. \& Tooley, M.J.

1155 (eds.): The Quaternary History of the Irish Sea., Geological Journal., Special Issue, 7.

1156 Pantin, H.M. 1978: Quaternary sediments from the north-east Irish Sea, Isle of Man to Cumbria.

1157 Bulletin of the Geological Survey of Great Britain 64.

1158 Pantin, H.M. \& Evans, C.D.R. 1984: The Quaternary history of the Central and Southern Celtic Sea.

1159 Marine Geology 57, 259-293.

1160 Peacock, J.D.,1993: Late Quaternary marine Mollusca as palaeoenvironmental proxies: a

1161 complication and assessment of basic numerical data for NE Atlantic species found in shallow

$1162 \quad$ water. Quaternary Science Reviews 12, 263-275.

1163 Peltier, W.R., Shennan, I., Drummond, R. \& Horton, B. 2002: On the postglacial isostatic adjustment

1164 of the British Isles and the shallow viscoelastic structure of the Earth. Geophysical Journal

1165 International 148, 443-475.

1166 Pieńkowski, A.J., England, J.H., Furze, M.F.A., Marret, F., Eynaud, F., Vilks, G., MacLean, B., Blasco, S.

1167 \& Scourse, J.D. 2012: The deglacial to postglacial environments of southeastern Barrow Strait, 1168 Canadian Arctic Archipelago. Boreas 41, 141-179.

1169 Pieńkowski, J.A., England, J.H. Furze, M.F.A., Blasco, S., Mudie, P.J. \& MacLean, B. Submitted. 11,000

1170 years of environmental change in the Northwest Passage: a multiproxy core record from central

1171 Parry Channel, Canadian High Arctic. Marine Geology.

1172 Pospelova, V., Chmura, G.L. \& Walker, H.A. 2004: Environmental factors influencing the spatial

1173 distribution of dinoflagellate cyst assemblages in shallow lagoons of southern New England

1174 (USA). Review of Palaeobotany and Palynology 128, 7-34.

1175 Pospelova, V., Chmura, G.L., Boothman, W.S. \& Latimer, J.S. 2005: Spatial distribution of modern

1176 dinoflagellate cysts in polluted estuarine sediments from Buzzards Bay (Massachusetts, USA)

1177 embayments. Marine Ecology Progress Series 292, 23-40. 
1178 Post, A.L., Hemer, M.A., O’Brien, P.E., Roberts, D., Craven, M., 2007: History of benthic colonisation

1179 beneath the Amery Ice Shelf, East Antarctica. Marine Ecology Progress Series 344, 29-37.

1180 Powell, R.D. 1984: Glacimarine processes and inductive lithofacies modelling of ice shelf and 1181 tidewater glacier sediments based on Quaternary examples. Marine Geology 57, 1-52.

1182 Praeg, D., McCarron S. \& Stoker, M. 2011: New evidence on glaciation of the Celtic Sea: results from 1183 GLAMAR. XVIII INQUA Congress Bern, Switzerland Abstract, 2490.

1184 Preece, R.C., Coxon, P. \& Robinson, J.E. 1986: New biostratigraphic evidence of the Post-glacial

1185 colonization of Ireland and for Mesolithic forest disturbance. Journal of Biogeogeography 13, $1186 \quad 497-509$.

1187 Reid, P.C. 1975: A regional sub-division of dinoflagellate cysts around the British Isles. New $1188 \quad$ Phytologist 75, 589-603.

1189 Reimer, P.J., McCormac, F.G, Moore, J., McCormick, F. \& Murray, E.V. 2002: Marine radiocarbon 1190 reservoir corrections for the mid- to late Holocene in the eastern subpolar North Atlantic. The $1191 \quad$ Holocene 12, 129-135.

1192 Reimer P.J., Baillie, M.G.L., Bard, E. et al. 2009: IntCal09 and Marine09 radiocarbon age calibration 1193 curves, 0-50,000 years cal BP. Radiocarbon 51, 1111-1150.

1194 Reynaud, J.-Y., Tessier, B., Proust, J.-N., Lericolais, G., Marsset, T., Berné, S. \& Chamley, H. 1985:

1195 Apports de la sismique très haute résolution à l'interprétation génétique d'un banc sableux de 1196 la Mer Celtique. Comptes Rendus Academie de Science Paris 320 (Ila), 125-132.

1197 Reynaud, J.-Y., Tessier, B., Proust, J.-N., Dalrymple, R., Marsset, T., De Batist, M., Bourillet, J.-F. \& 1198 Lericolais, G., 1999: Eustatic and hydrodynamic controls on the architecture of a deep shelf sand 1199 bank (Celtic Sea). Sedimentology 46, 703-721.

1200 Reynaud, J.-Y., Tessier, B., Auffret, J.-P., Berné, S., Batist, M. D., Marsset, T. and Walker, P. 2003: The 1201 offshore Quaternary sediment bodies of the English Channel and its Western Approaches.

1202 Journal of Quaternary Science 18, 361-371. 
Riding J.B. 1997: A Palynological Investigation of Sediments from Cardigan No 1 and No 2 Boreholes.

1204 Technical ReportWH/97/214R, British Geological Survey: Keyworth.

1205 Rijsdijk K.F., Warren W.P \& Van der Meer J.J.M. 2010: The deglacial sequence at Killiney, SE Ireland:

1206 terrestrial sedimentation and glaciotectonics. Quaternary Science Reviews. 29, 696-719.

1207 Rippeth, T.P., Scourse, J.D., Uehara, K. \& McKeown, S. 2008: Impact of sea-level rise over the last

1208 deglacial transition on the strength of the continental shelf $\mathrm{CO}_{2}$ pump. Geophysical Research

$1209 \quad$ Letters 35, L24604, doi:10.1029/2008GL035880

1210 Roberts, D.H., Dackombe, R.V. \& Thomas, G.S.P. 2007: Palaeo-ice streaming in the central sector of

1211 the Britishlrish Ice Sheet during the Last Glacial Maximum: evidence from the northern Irish Sea

$1212 \quad$ Basin. Boreas 36, 115-129.

1213 Roberts, M.J., Scourse, J.D., Bennell, J.D., Huws, D.G., Jago, C.F. \& Long, B.T. 2011: Late Devensian

1214 and Holocene relative sea-level change in North Wales, UK. Journal of Quaternary Science 26, $1215 \quad 141-155$.

1216 Rochon, A., de Vernal, A., Turon, J.-L., Matthiessen, J. \& Head M. 1999: Distribution of Recent

1217 dinoflagellate cysts in surface sediments from the North Atlantic Ocean and adjacent seas in

1218 relation to sea-surface parameters. American Association of Stratigraphic Paleontologists

$1219 \quad$ Contributions Series 35, 1-150.

1220 Scourse, J.D. 1991a: Late Pleistocene stratigraphy and palaeobotany of the Isles of Scilly.

1221 Philosophical Transactions of the Royal Society of London B334, 405-448.

1222 Scourse, J.D. 1991b: Glacial deposits of the Isles of Scilly. In Ehlers, J., Gibbard, P.L. \& Rose, J. (eds.):

1223 Glacial Deposits in Great Britain and Ireland. A.A. Balkema, Rotterdam. 291-300.

1224 Scourse, J.D. In press. Quaternary sea level and palaeotidal changes: a review of impacts on, and 1225 responses of, the marine biosphere. Oceanography and Marine Biology: An Annual Review.

1226 Scourse, J.D. \& Austin, W.E.N. 1994: A Devensian Late-glacial and Holocene sea-level and water 1227 depth record from the central Celtic Sea. Quaternary Newsletter 74, 22-29. 
1228 Scourse, J.D. \& Furze, M.F.A. 2001: A critical review of the glacimarine model for Irish Sea

1229 deglaciation: evidence from southern Britain, the Celtic shelf and adjacent continental slope.

$1230 \quad$ Journal of Quaternary Science 16, 419-434.

1231 Scourse, J.D., Austin, W.E.N., Bateman, R.M., Catt, J.A., Evans, C.D.R., Robinson, J.E. \& Young, J.R.

1232 1990: Sedimentology and micropaleontology of glacimarine sediments from the Central and

1233 Southwestern Celtic Sea. In Dowdeswell, J.A. \& Scourse, J.D. (eds.): Glacimarine environments:

1234 processes and sediments. Geological Society Special Publication 53, 369-387.

1235 Scourse, J.D., Robinson, J.E. \& Evans, C.D.R. 1991: Glaciation of the central and southwestern Celtic

1236 Sea. In Ehlers, J., Gibbard, P.L. \& Rose, J. (eds.): Glacial Deposits in Great Britain and Ireland. A.A.

1237 Balkema, Rotterdam. 301-310.

1238 Scourse, J.D., Austin, W.E.N., Long, B.T., Assinder, D.J. \& Huws, D. 2002: Holocene evolution of

1239 seasonal stratification in the Celtic Sea: refined age model, mixing depths and foraminiferal

$1240 \quad$ stratigraphy. Marine Geology 191, 119-145.

1241 Scourse, J.D., Uehara, K., \& Wainwright, A. 2009: Celtic Sea linear tidal sand ridges, the Irish Sea Ice

1242 Stream and the Fleuve Manche: palaeotidal modelling of a transitional passive margin

1243 depositional system. Marine Geology 259, 102-111.

1244 Sejrup, H.P., Hjelstuen, B.O., Dahlgren, K.I.T., Haflidason, H., Kuijpers, A., Nygård, A., Praeg, D.,

1245 Stoker, M.S. \& Vorren, T.O. 2005: Pleistocene glacial history of the NW European continental

1246 margin. Marine and Petroleum Geology 22, 1111-1129.

1247 Seyd, E.L. 1992: Moss mites (Acari: Oribatida) in a lichen sample from Mount Leinster, Co. Carlow,

1248 Eire, and their bearing on a land connection between Britain and Ireland during the Quaternary

1249 and Post-glacial times. Journal of Biogeography 19, 401-409.

1250 Shennan, I., Bradley, S., Milne, G., Brooks, A., Bassett, S. and Hamilton, S. 2006: Relative sea-level

1251 changes, glacial isostatic modelling and ice-sheet reconstructions from the British Isles since the

1252 Last Glacial Maximum. Journal of Quaternary Science 21, 585-599. 
1253 Stewart, J.R. \& Lister, A.M. 2001: Cryptic northern refugia and the origins of the modern biota.

1254 Trends in Ecology \& Evolution 16, 608-613.

1255 Stuart, A.J. 1977: The vertebrates of the Last Cold Stage in Britain and Ireland. Philosophical

1256 Transactions of the Royal Society of London B280, 295-312.

1257 Stuart, A.J. 1995: Insularity and Quaternary vertebrate faunas in Britain and Ireland. In Preece, R.C.

1258 (ed.): Island Britain: a Quaternary perspective. Geological Society Special Publication 96, 111-

$1259 \quad 125$.

1260 Stuart, A.J. \& van Wijngaarden-Bakker, L.H. 1985: Chapter 10:- Quaternary Vertebrates. In Edwards,

1261 K.J. \& Warren, W.P. (eds.): The Quaternary History of Ireland. Academic Press, London, 221-249.

1262 Stuiver, M., Reimer, P.J., Reimer, R.W., 2010: CALIB 6.0 [WWW programme and documentation].

1263 Syvitski, J.P.M. 1991: Towards an understanding of sediment deposition on glaciated continental

1264 shelves. Continental Shelf Research 11, 897-937.

1265 Tappin, D.R., Chadwick, R.A., Jackson, A.A., Wingfield, R.T.R. \& Smith, N.J.P. 1994: The geology of

1266 Cardigan Bay and the Bristol Channel. British Geological Survey U.K. Offshore Regional Report.

1267 HMSO, London.

1268 Teacher, A.G.F., Garner, T.W.J. \& Nichols, R.A. 2009: European phylogeography of the common frog

1269 (Rana temporaria): routes of postglacial colonization into the British Isles, and evidence for an

$1270 \quad$ Irish glacial refugium. Heredity 102, 490-496.

1271 Tebble, N. 1976: British Bivalve Seashells: a handbook for identification (2 ${ }^{\text {nd }}$ edition). HMSO,

$1272 \quad$ Edinburgh.

1273 Tesch, J.J. 1947: Pteropoda Thecosomata. Conseil international pour L'exploration de la Mer,

$1274 \quad$ Zooplanton, Sheet 8.

1275 Thomas, G.S.P., Chiverrell, R.C. \& Huddart, D. 2004: Ice-marginal depositional responses to

1276 readvance episodes in the Late Devensian deglaciation of the Isle of Man. Quaternary Science

1277 Reviews 23, 85-106. 
1278 Thompson, T.E. \& Brown, G.H. 1976: British Opisthobranch Molluscs. Linnean Society Synopses of the

1279 British Fauna (ns) 8, 1-203.

1280 Thomsen, E. \& Vorren, T.O. 1986: Macrofaunal palaeoecology and stratigraphy in Late

1281 Quaternaryshelf sediments off northern Norway. Palaeogeography, Palaeoclimatology,

$1282 \quad$ Palaeoecology 56, 103-150.

1283 Uehara, K., Scourse, J.D., Horsburgh, K.J., Lambeck, K. \& Purcell, A.P. 2006: Tidal evolution of the

1284 northwest European shelf seas from the Last Glacial Maximum to the present. Journal of

$1285 \quad$ Geophysical Research 111, C09025, doi:10.1029/2006JC003531.

1286 Van Landeghem, K.J.J., Wheeler, A.J. \& Mitchell, N.C. 2009: Seafloor evidence for palaeo-ice

1287 streaming and calving of the grounded Irish Sea Ice Stream: Implications for the interpretation

1288 of its final deglaciation phase. Boreas $38,119-131$.

1289 Wingfield, R.T.R. 1989: Glacial incisions indicating Middle and Upper Pleistocene ice limits off Britain.

$1290 \quad$ Terra Nova 1, 538-548.

1291 Wingfield, R.T.R. 1990: The origin of major incisions within the Pleistocene deposits of the North Sea.

$1292 \quad$ Marine Geology 91, 31-52.

1293 Wingfield, R.T.R. 1995: A model of sea-level in the Irish and Celtic Seas during the end-Pleistocene to

1294 Holocene transition. In Preece, R.C. (ed.): Island Britain: a Quaternary perspective. Geological

1295 Society Special Publication 96, 209-242.

1296 Wingfield, R.T.R. 1996: Erosional effects on morphological sea-level indicators. In Plag, H.-P., Austin,

1297 W.E.N., Belknap, D.F., Devoy, R.J.N., England, J.H., Josenhans, H., Peacock, J.D., Petersen, K.S.,

1298 Rokoengen, K., Scourse, J.D., Smith, D.E. \& Wingfield, R.T.R.: Late Quaternary relative sea-level

1299 changes and the role of glaciation upon the continental shelves. Terra Nova 8, 215-216

1300 Wollast, R. 1991: The coastal organic carbon cycle: Fluxes, sources, and sinks, In Mantoura, R.F.C.,

1301 Martin, J.-M. \& Wollast, R. (eds.): Ocean margin processes in global change: report of the

1302 Dahlem Workshop on Ocean Margin Processes in Global Change, Berlin, 1990, March 18-23.

$1303 \quad$ Wiley, Berlin 


\section{Page 53 of 65}

1

2

3

4

5

6

7

8

9

10

11

12

13

14

15

16

17

18

19

20

21

22

23

24

25

26

27

28

29

30

31

32

33

34

35

36

37

38

39

40

41

42

43

44

45

46

47

48

49

50

51

52

53

54

55

56

57

58

59

60
1304 Woodman, P., McCarthy, M. \& Monaghan, N. 1997: The Irish Quaternary Fauna Project. Quaternary

1305 Science Reviews 16, 129-159.

1306 Yalden, D.W. 1982: When did the mammal fauna of the British Isles arrive? Mammal Review 12, 1-

$1307 \quad 57$.

1308

1309 


\section{List of Figures and Tables}

1311 Fig. 1 Map of study area and inset of northern and central Celtic Sea continental shelf showing

1312 bathymetry and core locations.

1313

1314 Fig. 2 Stratigraphies of British Geological Survey vibrocores from the northern and central Celtic Sea

1315 used in this study. For core locations and details, refer to Fig. 1 and Table 1. Lithostratigraphic codes

1316 are modified from Eyles et al. (1983). $\mathrm{Dm}=$ matrix-supported diamicton; $\mathrm{F}=$ fines; $\mathrm{Gm}=$ matrix-

1317 supported gravel; $\mathrm{S}=$ sand $\mathrm{h}=$ horizontal laminations; $\mathrm{I}=$ fine laminations; $(\mathrm{I})=$ very faint fine

1318 laminations; $\mathrm{m}=$ massive; $-\mathrm{s}=$ shelly .

1319

1320 Fig. 3 Absolute abundances of macrofossil groups in analyzed British Geological Survey vibrocores

1321 (Fig. 1) from the Celtic Sea. Core samples are grouped by regionally-extensive stratigraphic units I, II, 1322 and III present in the study area, including subunits.

1323

1324 Fig. 4 Results of organic-walled microfossil analyses on the Celtic Sea samples. (A) Dinoflagellate 1325 cysts. (B) Other non-pollen palynomorphs and pollen and spores. Core samples are grouped by 1326 regionally-extensive stratigraphic units I, II, and III present in the study area, including subunits.

1328 Table 1 Details of British Geological Survey vibrocore examined in the present study, including core 1329 number, location, and core code used in the text.

1330

1331 Table 2 Details of radiocarbon dates used in this study. 


\section{Page 55 of 65}

\section{Boreas}

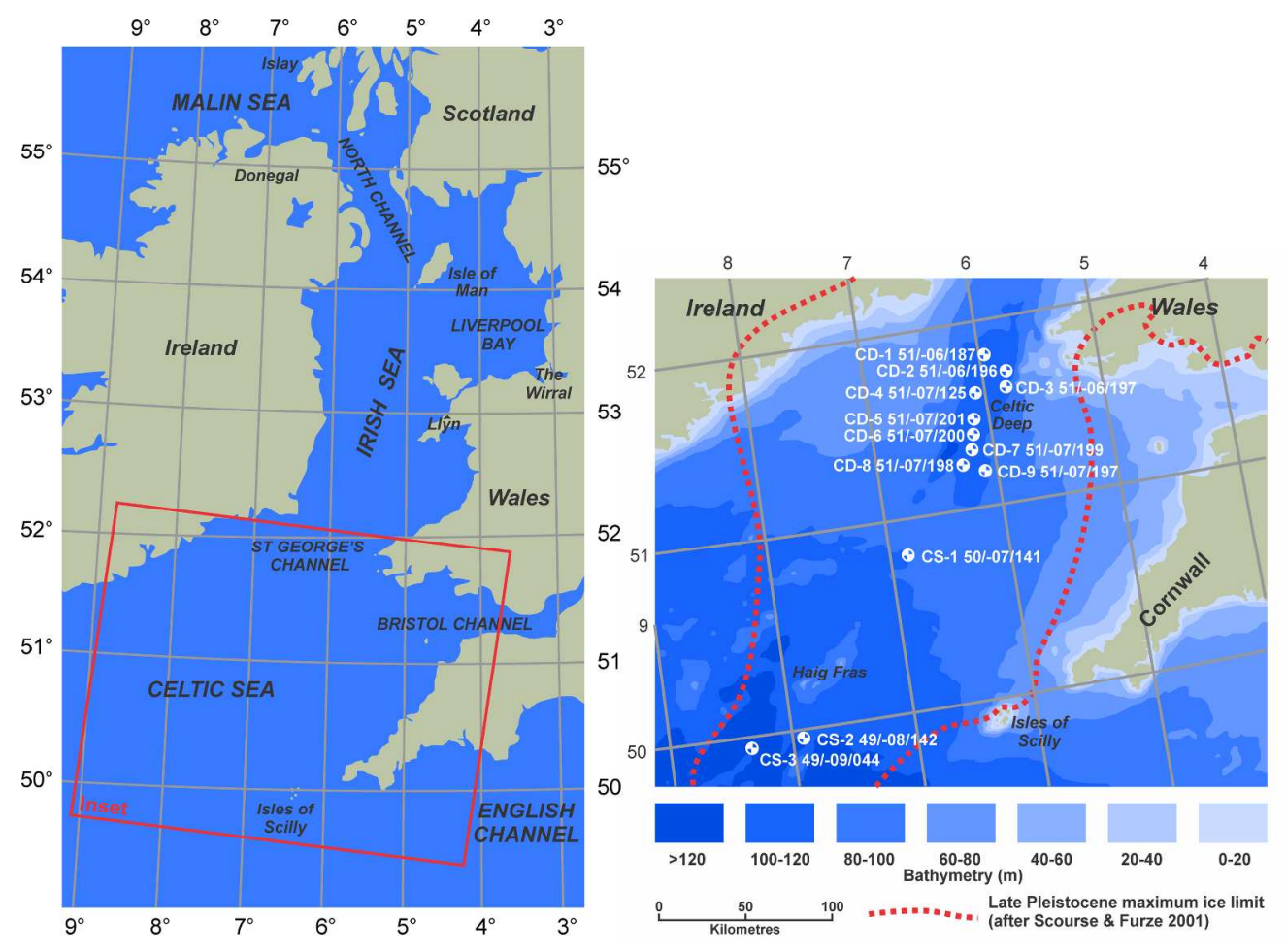

Fig. 1 Map of study area and inset of northern and central Celtic Sea continental shelf showing bathymetry and core locations. $124 \times 90 \mathrm{~mm}(600 \times 600 \mathrm{DPI})$ 


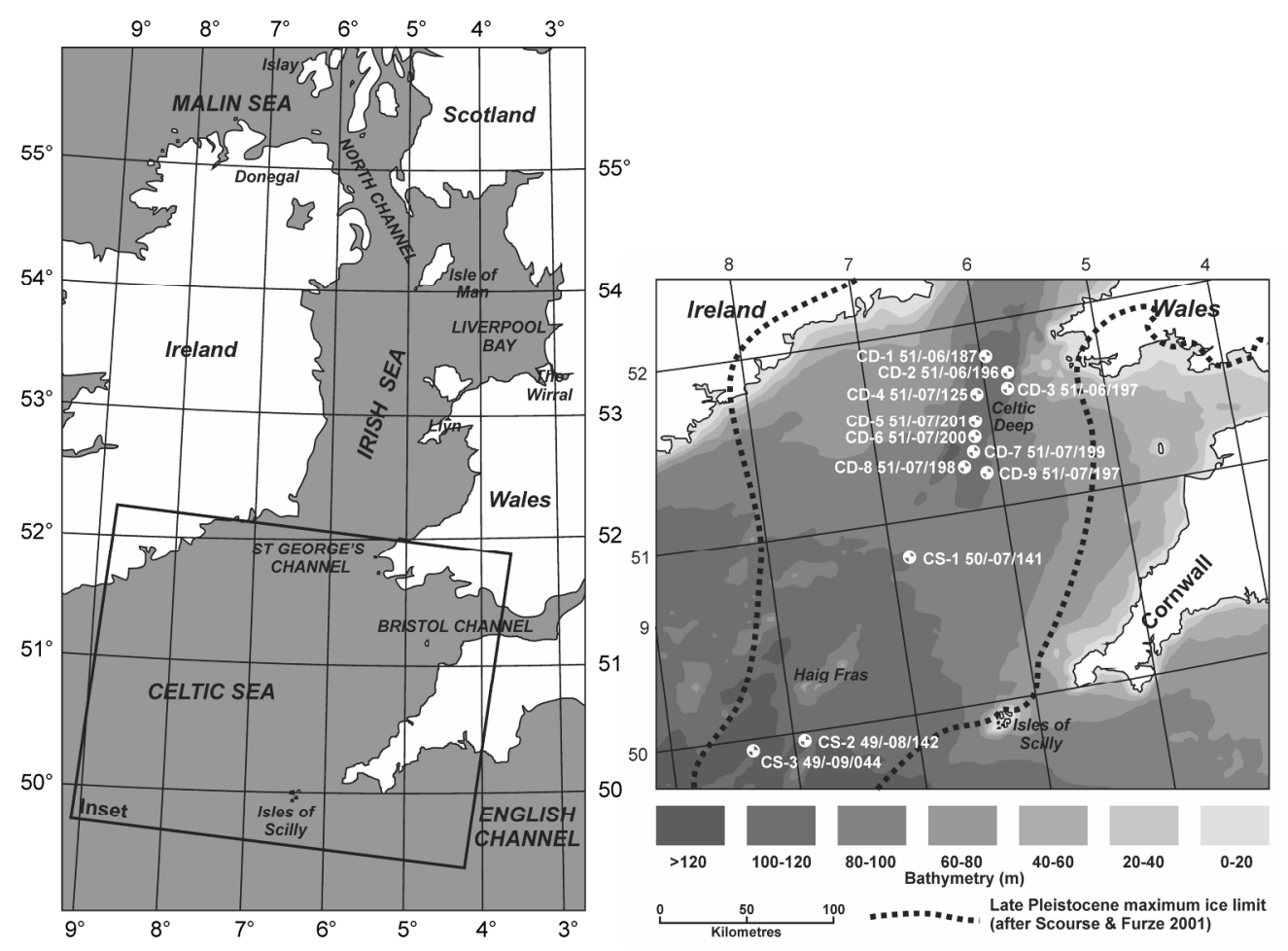

Fig. 1 Map of study area and inset of northern and central Celtic Sea continental shelf showing bathymetry and core locations. $124 \times 90 \mathrm{~mm}(600 \times 600 \mathrm{DPI})$ 

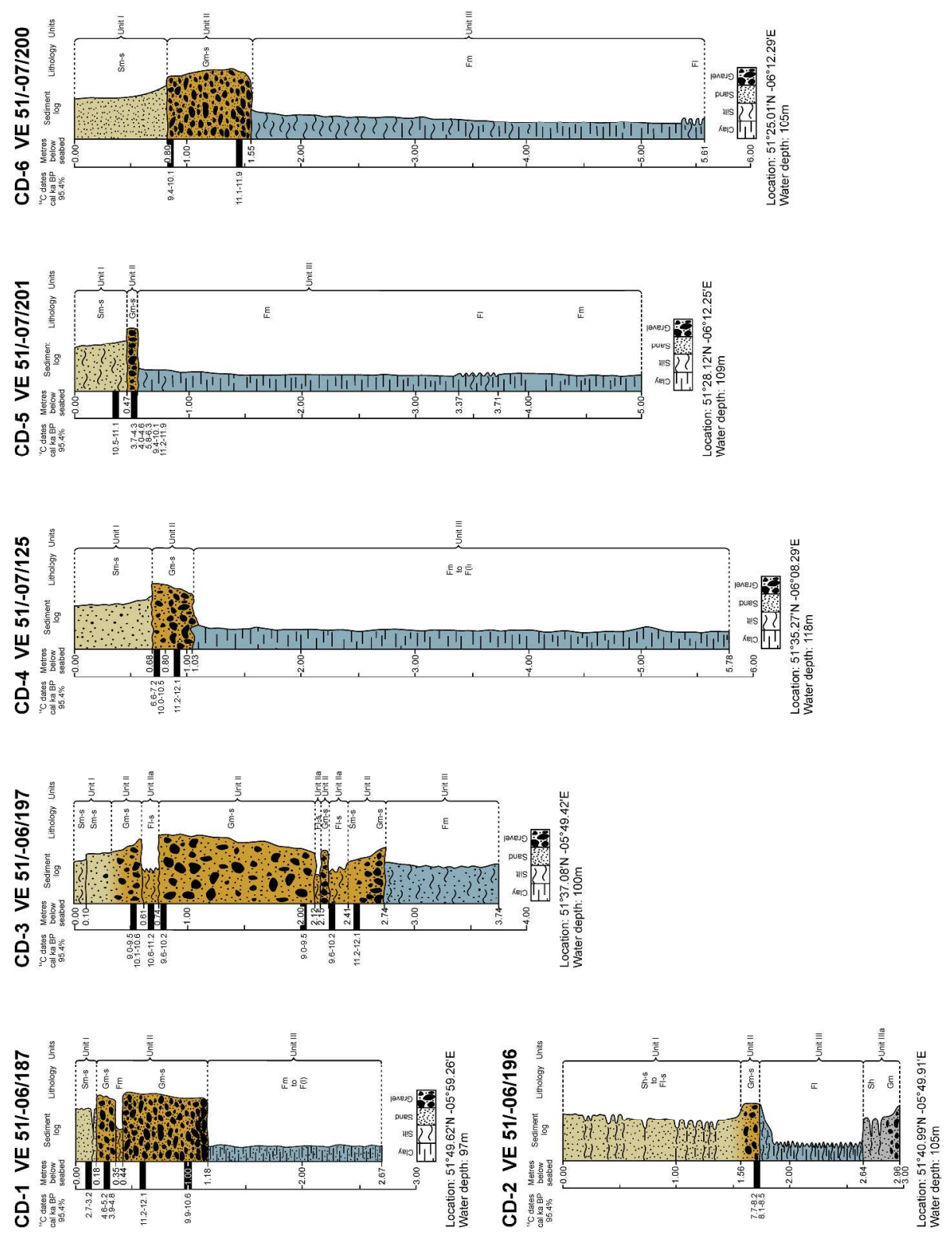

Fig. 2 Stratigraphies of British Geological Survey vibrocores from the northern and central Celtic Sea used in this study. For core locations and details, refer to Fig. 1 and Table 1. Lithostratigraphic codes are modified from Eyles et al. (1983). Dm = matrix-supported diamicton; $\mathrm{F}=$ fines; $\mathrm{Gm}=$ matrix-supported gravel; $\mathrm{S}=$ sand $\mathrm{h}=$ horizontal laminations; $\mathrm{I}=$ fine laminations; $(\mathrm{I})=$ very faint fine laminations; $\mathrm{m}=$ massive; $-\mathrm{s}=$ shelly. 

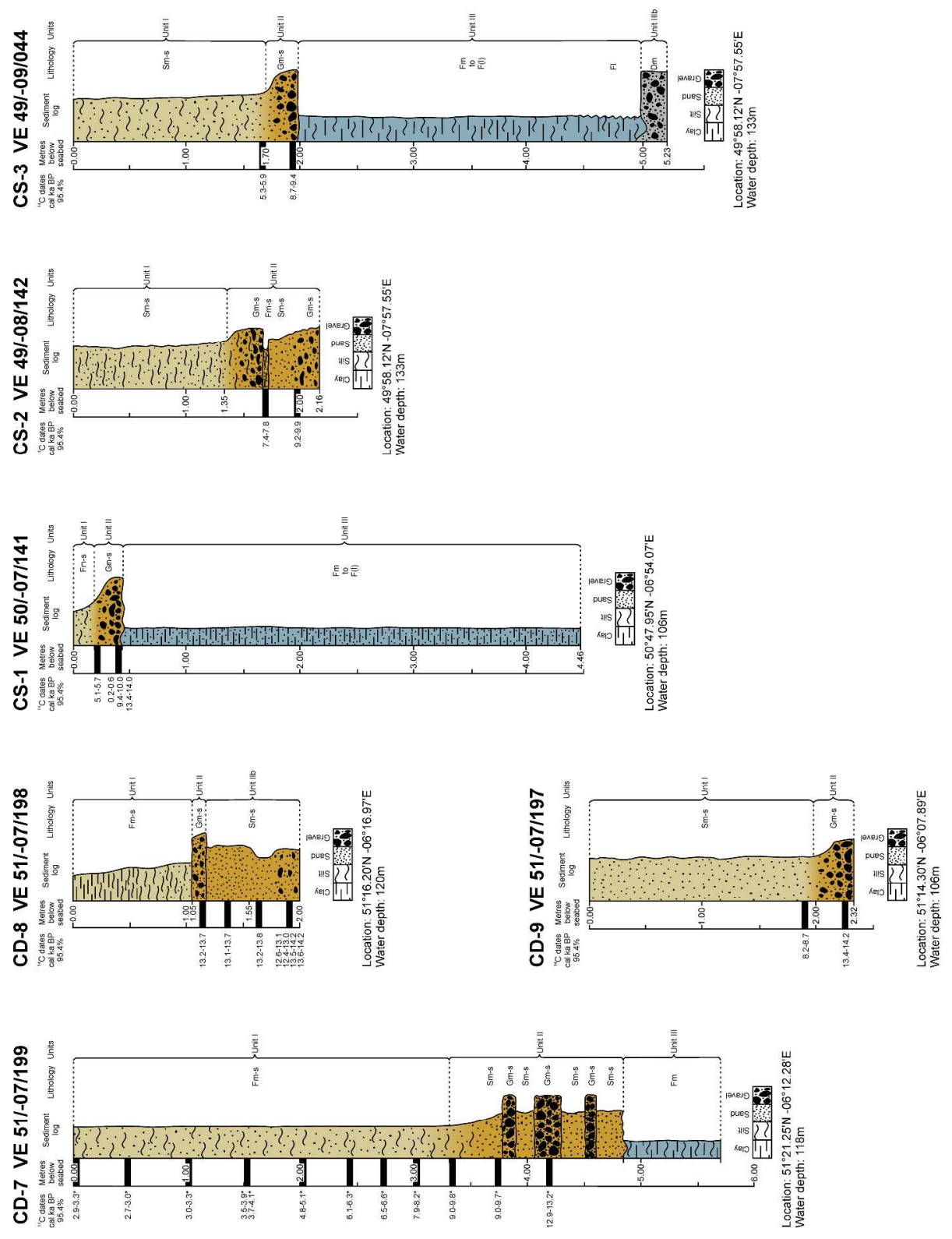

Fig. 2 Stratigraphies of British Geological Survey vibrocores from the northern and central Celtic Sea used in this study. For core locations and details, refer to Fig. 1 and Table 1. Lithostratigraphic codes are modified from Eyles et al. (1983). Dm = matrix-supported diamicton; $\mathrm{F}=$ fines; $\mathrm{Gm}=$ matrix-supported gravel; $\mathrm{S}=$ sand $\mathrm{h}=$ horizontal laminations; $\mathrm{I}=$ fine laminations; $(\mathrm{I})=$ very faint fine laminations; $\mathrm{m}=$ massive; $-\mathrm{s}=$ shelly. 

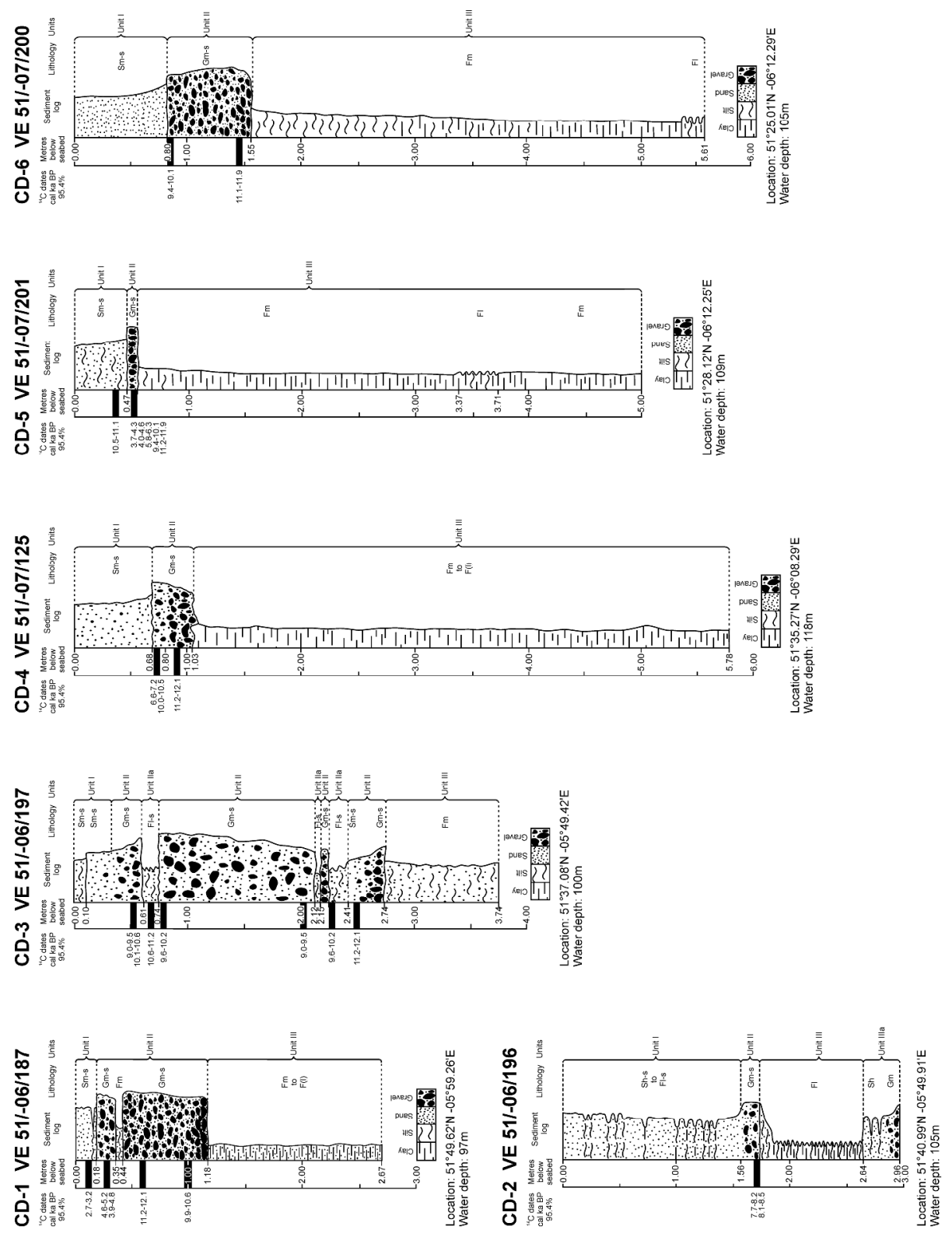

Fig. 2 Stratigraphies of British Geological Survey vibrocores from the northern and central Celtic Sea used in this study. For core locations and details, refer to Fig. 1 and Table 1. Lithostratigraphic codes are modified from Eyles et al. (1983). Dm = matrix-supported diamicton; $\mathrm{F}=$ fines; $\mathrm{Gm}=$ matrix-supported gravel; $\mathrm{S}=$ sand $\mathrm{h}=$ horizontal laminations; $\mathrm{I}=$ fine laminations; $(\mathrm{I})=$ very faint fine laminations; $\mathrm{m}=$ massive; $-\mathrm{s}=$ shelly. 
Fig. 2 Stratigraphies of British Geological Survey vibrocores from the northern and central Celtic Sea used in this study. For core locations and details, refer to Fig. 1 and Table 1. Lithostratigraphic codes are modified from Eyles et al. (1983). Dm = matrix-supported diamicton; $\mathrm{F}=$ fines; $\mathrm{Gm}=$ matrix-supported gravel; $\mathrm{S}=$ sand; $\mathrm{h}=$ horizontal laminations; $\mathrm{I}=$ fine laminations; $(\mathrm{I})$ = very faint fine laminations; $\mathrm{m}=$ massive; $-\mathrm{s}=$ shelly. 
Fig. 3 Absolute abundances of macrofossil groups in analyzed British Geological Survey vibrocores (Fig. 1) from the Celtic Sea. Core samples are grouped by regionally-extensive stratigraphic units I, II, and III present in the study area, including subunits. 

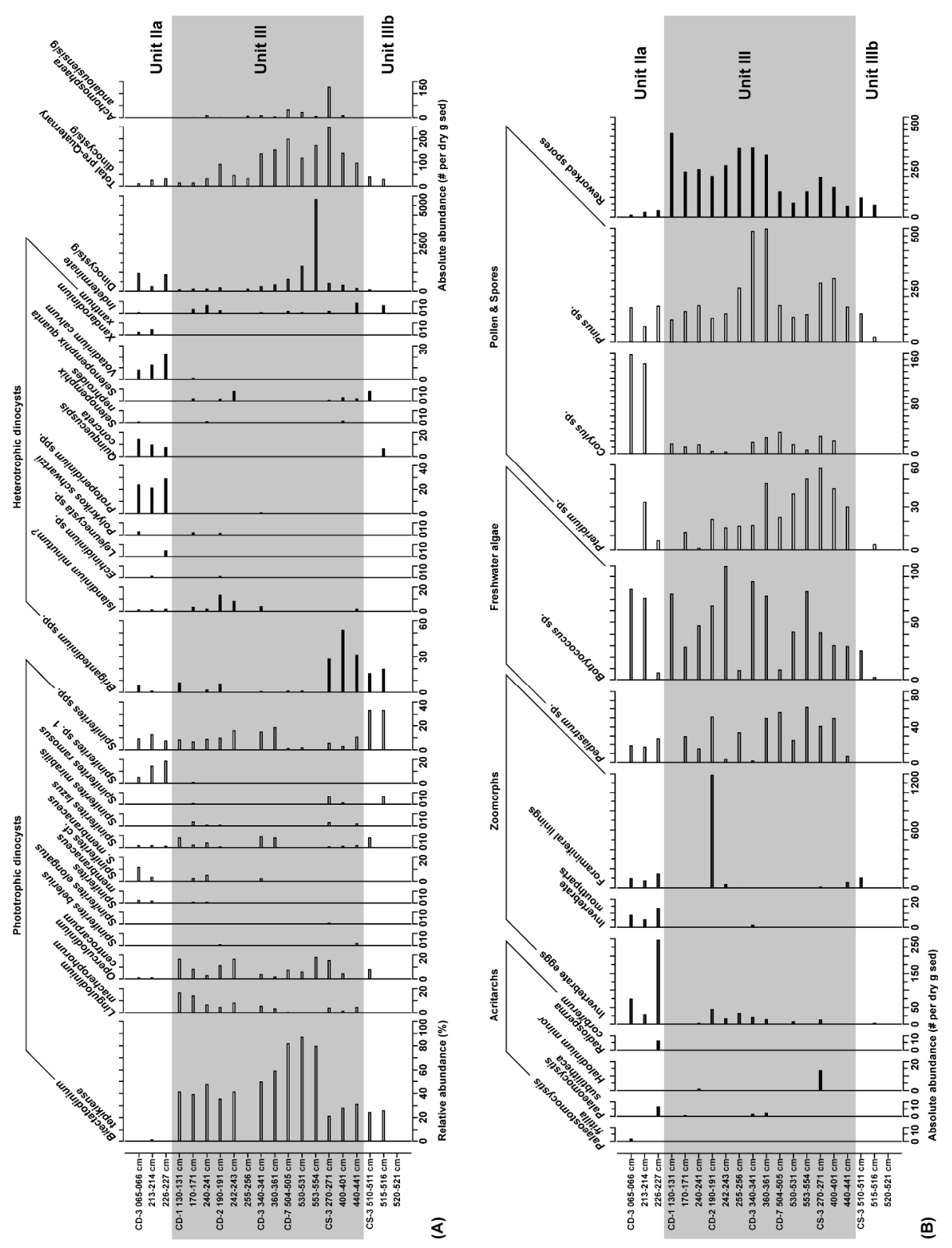

Fig. 4 Results of organic-walled microfossil analyses on the Celtic Sea samples. (A) Dinoflagellate cysts. (B) Other non-pollen palynomorphs and pollen and spores. Core samples are grouped by regionally-extensive stratigraphic units I, II, and III present in the study area, including subunits. 


\section{Page 63 of 65}

Boreas

\begin{tabular}{llllcclr}
$\begin{array}{l}\text { Core } \\
\text { Code }\end{array}$ & $\begin{array}{l}\text { BGS } \\
\text { Core Number }\end{array}$ & Lat. $N$ & Long. W & $\begin{array}{l}\text { Water } \\
\text { Depth (m) }\end{array}$ & $\begin{array}{l}\text { Core } \\
\text { Length }(\mathbf{c m})\end{array}$ & $\begin{array}{l}\text { Research } \\
\text { Vessel }\end{array}$ & \multicolumn{1}{l}{$\begin{array}{l}\text { Recovery } \\
\text { Date }\end{array}$} \\
\hline CD-1 & VE 51/-06/187 & $51^{\circ} 49.62^{\prime}$ & $05^{\circ} 59.26^{\prime}$ & 97 & 267 & MV Steelfish & $8 / 12 / 1973$ \\
CD-2 & VE 51/-06/196 & $51^{\circ} 40.99^{\prime}$ & $05^{\circ} 49.91^{\prime}$ & 105 & 296 & MV Steelfish & $8 / 13 / 1973$ \\
CD-3 & VE 51/-06/197 & $51^{\circ} 37.08^{\prime}$ & $05^{\circ} 49.42^{\prime}$ & 100 & 374 & MV Steelfish & $8 / 13 / 1973$ \\
CD-4 & VE 51/-07/125 & $51^{\circ} 35.27^{\prime}$ & $06^{\circ} 08.29^{\prime}$ & 118 & 578 & MV Whitehorn & $9 / 4 / 1982$ \\
CD-5 & VE 51/-07/201 & $51^{\circ} 28.12^{\prime}$ & $06^{\circ} 12.25^{\prime}$ & 109 & 500 & MV Whitehorn & $9 / 8 / 1982$ \\
CD-6 & VE 51/-07/200 & $51^{\circ} 25.01^{\prime}$ & $06^{\circ} 12.29^{\prime}$ & 105 & 561 & MV Whitehorn & $9 / 8 / 1982$ \\
CD-7 & VE 51/-07/199 & $51^{\circ} 21.25^{\prime}$ & $06^{\circ} 12.23^{\prime}$ & 118 & 568 & MV Whitehorn & $9 / 8 / 1982$ \\
CD-8 & VE 51/-07/198 & $51^{\circ} 16.20^{\prime}$ & $06^{\circ} 16.97^{\prime}$ & 120 & 200 & MV Whitehorn & $9 / 8 / 1982$ \\
CD-9 & VE 51/-07/197 & $51^{\circ} 14.30^{\prime}$ & $06^{\circ} 07.89^{\prime}$ & 106 & 232 & MV Whitehorn & $9 / 8 / 1982$ \\
CS-1 & VE 50/-07/141 & $50^{\circ} 47.95^{\prime}$ & $06^{\circ} 54.07^{\prime}$ & 106 & 446 & MV Briarthorn & $6 / 3 / 1974$ \\
CS-2 & VE 49/-08/142 & $49^{\circ} 58.12^{\prime}$ & $07^{\circ} 57.55^{\prime}$ & 133 & 216 & MV Emerald & $6 / 18 / 1977$ \\
CS-3 & VE 49/-09/044 & $49^{\circ} 57.80^{\prime}$ & $08^{\circ} 20.24^{\prime}$ & 127 & 523 & MV Cape Shore & $8 / 7 / 1978$
\end{tabular}


Sample Litho.

Laboratory

Median Prob. Age Calibrated Ages Ranges (cal yrs BP)

3

Depth (cm) Unit

Material Description

Number

$\delta^{13} \mathrm{C} \quad{ }^{14} \mathrm{C}$ Age $\pm \quad$ (cal yrs BP) $68.2 \%$ interval

95.4\% interval

$\begin{array}{lllllllll}010-015 & \text { I } & \text { Bivalve } & \text { Mimachlamys varia } & \text { AA-36237 } & 1.60 & \mathbf{3 0 4 5} & \mathbf{5 0} & 2870\end{array}$

$\begin{array}{llll}1.60 & \mathbf{3 0 4 5} & \mathbf{5 0} & 2870 \\ 216 & \mathbf{4 6 3 0} & 25 & 4910\end{array}$

$2980-2740$

3180 - 2660

025-030 II Bivalve Mimachlamys varia

AA-36238

410050

4200

060-065 II Bivalve Spisula elliptica

AA-36239

2.70

1044575

11620

$\begin{array}{lllll}\text { AA-36240 } & 1.60 & 9390 & 95 & 10280\end{array}$

$5040-4780$

$5220-4640$

098-103

Bivalve

Timoclea ovata

AA-36185

$\begin{array}{llll}0.60 & \mathbf{7 4 5 0} & \mathbf{5 5} & 7950\end{array}$

160-165 II Bivalve Nucula sulcata ${ }^{\dagger}$

AA-36186

1.50

781060

Gastropod Tornus subcarinatus *

OS-79219

050-055

063-068

Bivalve

Venus casina

AA-36241

1.39

$8630 \quad 60$

8300

4360 - 4060

4480 - 3900

075-080

200-205

220-225

245-250

Bivalve

Ostrea edulis

AA-36242 1.90

$\begin{array}{lll}\mathbf{9 4 3 0} & \mathbf{7 0} & 10320\end{array}$

$992590 \quad 10900$

Aequipecten opercularis

AA-36243

1.00

$\begin{array}{lllll}\text { Spisula elliptica } & \text { AA-36244 } & 1.40 & \mathbf{8 6 0 5} & \mathbf{6 5}\end{array}$

OS-79103

$-0.23$

$9110-40$

Abra cf. alba, left valve

AA-36245

1.40

$10445 \quad 85$

9950

9290

$11860-11360$

$12050-11230$

Spisula elliptica

$070-075$

090-095

Gastropod Crisilla semistriata *

3.20

$9390 \quad 70$

11630

8060 - 7820

$8170-7710$

$8400-8180$

8530 - 8060

$9460-9200$

$10450-10200$

$9520-9030$

11100 - 10740

$10570-10050$

$10140-9800$

$9430-9160$

$10100-9770$

$9500-9010$

11860 - 11360

12070 - 11220

- 10160

$10540 \quad-9960$

$6990-6710$

7150 - 6610

Bivalve Nucula turgida ${ }^{\dagger}$

AA-32279 $\quad 1.60 \quad \mathbf{1 0 4 6 0} \quad \mathbf{8 0} \quad 11650$

11880 - 11390

$12080-11230$

050-055

050-055

050-055

050-055

Bucula sulcata ${ }^{\dagger}$

Gastropod Turritella communis

$\begin{array}{lllll}\text { AA-32282 } & 1.10 & \mathbf{9 8 0 5} & \mathbf{8 5} & 10770\end{array}$

$10930-10570$

$11120-10500$

4470 - 4150

4630 - 3980

$\begin{array}{llllll}\text { AA-32284 } & 3.10 & \mathbf{3 9 6 0} & \mathbf{6 5} & 4010\end{array}$

$\begin{array}{lllll}\text { AA-32285 } & 3.20 & \mathbf{5 6 2 0} & \mathbf{6 5} & 6060\end{array}$

Gastropod Turritella communis

Bivalve Spisula elliptica

050-055

Nucula sulcata

AA-32286

4150 - 3840

$6180-5930$

9870 - 9520

$4330-3690$

$6290-5790$

11650 - 11220

$10110-9440$

9820 - 9510

$11920-11150$

143-148 II $\quad$ Bivalve Spisula elliptica

AA-32280

11

$11630-11200$

$10070 \quad-9440$

$\begin{array}{lllll}A A-32281 & 1.40 & \mathbf{1 0} 305 & \mathbf{7 5} & 11430\end{array}$

13570 - 13280

11870 - 11140

Nucula sulcata ${ }^{\dagger}$

130-135 II b Bivalve

Nucula sulcata

AA-36248

$\begin{array}{lll}1.60 & 11935 & 80\end{array}$

13420

$13500-13240$

$13720 \quad-13190$

160-165 II b Bivalve

Spisula elliptica

AA -36250

$\begin{array}{lll}2.10 & 11970 \quad 100\end{array}$

13460

13600 - 13310

$13670-13140$

190-195 II b Gastropod H. ulvae x1, R. parva x1*

OS-79120

$\begin{array}{lll}0.69 & \mathbf{1 2} 400 & \mathbf{5 0}\end{array}$

13890

$14000-13770$

13760 - 13210

190-195 II b Gastropod

cf. Rissoa parva *

OS-79121

$\begin{array}{lll}1.70 & 11250 & 45\end{array}$

$12870-12640$

$14150-13630$

12780 - 12570

$070-12580$

$14030-13760$

$12950-12400$

$\begin{array}{llllll}\mathrm{AA}-36251 & 2.00 & \mathbf{1 2} \mathbf{4 1 0} & \mathbf{8 5} & 13900\end{array}$

8570 - 8330

190-195

Bivalve

S. elliptca $\times 1$, T. ovata $x$

AA-36246

$\begin{array}{llll}0.60 & 7945 & 65 & 8450\end{array}$

$14020-13660$

8730 - 8180

Modiolus modiolus

AA-36247

$\begin{array}{llll}-0.20 & 12350 & 120 & 13840\end{array}$

$5550-5320$

$14190-13430$

Bivalve Dosinia lupinus

AA-36187

$\begin{array}{llll}1.20 & \mathbf{5 0 5 0} & \mathbf{5 0} & 5440\end{array}$

$9740-9470$

5680 - 5140

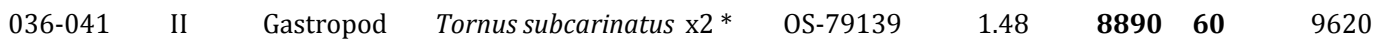

036-041

Gastropod

Tornus subcarinatus 2

OS-79147

$\begin{array}{lll}0.84 & 12250 & 80\end{array}$

13720

13870 - 13520

9990 - 9370

$500-320$

$13980-13430$

$630-240$ 
5 CS-3 VE 49/-09/044

$\begin{array}{lllllllll}167-172 & \text { II } & \text { Bivalve } & \text { Garifervensis } & \text { AA-32274 } & 2.90 & \mathbf{7 0 8 5} & \mathbf{6 0} & 7600 \\ 195-200 & \text { II } & \text { Bivalve } & \text { Spisula elliptica } & \text { AA-32275 } & 1.90 & \mathbf{8 7 8 5} & \mathbf{8 0} & 9490 \\ 165-170 & \text { I } & \text { Polychaete } & \text { Ditrupa arietina } & \text { AA-32276 } & 2.00 & \mathbf{5 2 2 0} & \mathbf{6 5} & 5620\end{array}$

$7690-7490$

$\mathbf{7 8 2 0}-\mathbf{7 4 1 0}$ 6

193-198 II Bivalve Spisula elliptica

AA-32277

1.50

$8420 \quad 70$

9070

$9640-9340$

$9850-9190$

7 Dates calibrated using CALIB 6.0 (Stuiver et al . 2010) and MARINE09 calibration curve (Reimer et al . 2009). $\Delta \mathrm{R}=-33 \pm 93$ (Reimer et al . 2002)

$\mathbf{5 7 3 0}-\mathbf{5 4 8 0}$

$\mathbf{5 8 8 0}-\mathbf{5 3 4 0}$

8 AA dates = NERC - University of Arizona dates, year of assay 1998/99 OS dates = NOSAMS dates, year of assay 2010

9 Species marked by * are grazers (gastropods), species marked by ${ }^{\dagger}$ are deposit feeders (bivalves) and likley subject to enhanced radiocarbon age effects due to the ingestion 10 of "old" carbonate (England et al. 2012), all other molluscs and polychaete dates are on filter-feeding taxa.

11 Species names according to World Register of Marine Species (Appeltans et al. 2011) 